\title{
Historic hydrovolcanism at Deception Island (Antarctica): implications for eruption hazards
}

Dario Pedrazzi, $1 \bowtie$

Emaildpedrazzi@ictja.csic.es

Károly Németh, 2

Adelina Geyer, 1

Antonio M. Álvarez-Valero, 3

Gerardo Aguirre-Díaz, 4

Stefania Bartolini, 1

1 ICTJA, CSIC, Group of Volcanology, SIMGEO UB-CSIC AQ1 , Institute of Earth Sciences Jaume Almera, Lluis Sole i Sabaris s/n, 08028 Barcelona, Spain

2 Volcanic Risk Solutions, CS-INR, Massey University, Private Bag 11 222, Palmerston North, New Zealand

3 Departamento de Geología, Universidad de Salamanca, 37008 Salamanca, Spain

4 Centro de Geociencias, Universidad Nacional Autónoma de México, Campus Juriquilla, 76230 Querétaro, QRO, Mexico

Received: 18 October 2017 / Accepted: 7 December 2017

\begin{abstract}
Deception Island (Antarctica) is the southernmost island of the South Shetland Archipelago in the South Atlantic. Volcanic activity since the eighteenth century, along with the latest volcanic unrest episodes in the twentieth and twentyfirst centuries, demonstrates that the volcanic system is still active and that future eruptions are likely. Despite its remote location, the South Shetland Islands are an important touristic destination during the austral summer. In addition, they host several research stations and three summer field camps. Deception Island is characterised by a Quaternary caldera system with a post-caldera succession and is considered to be part of an active, dispersed (monogenetic), volcanic field. Historical post-caldera volcanism on Deception Island involves monogenetic small-volume (VEI 2-3) eruptions such forming cones and various types of hydrovolcanic edifices. The scientific stations on the island were destroyed, or severely damaged, during the eruptions in 1967, 1969, and 1970 mainly due to explosive activity triggered by the interaction of rising (or erupting) magma with surface water, shallow groundwater, and ice. We conducted a detailed revision (field petrology and geochemistry) of the historical hydrovolcanic post-caldera eruptions of Deception Island with the aim to understand the dynamics of magma-water interaction, as well as characterise the most likely eruptive scenarios from future eruptions. We specifically focused on the Crimson Hill (estimated age between 1825 and 1829), and Kroner Lake (estimated age between 1829 and 1912) eruptions and 1967, 1969, and 1970 events by describing the eruption mechanisms related to the island's hydrovolcanic activity. Data suggest that the main hazards posed by volcanism on the island are due to fallout, ballistic blocks and bombs, and subordinate, dilute PDCs. In addition, Deception Island can be divided into five areas of expected activity due to magma-water interaction, providing additional data for correct hazard assessment on the island.
\end{abstract}

\section{Keywords}
Crimson Hill
Kroner Lake
Monogenetic volcanism
South Shetland Islands
Historical activity
Hydrovolcanism

Editorial responsibility: J. Taddeucci 


\section{Electronic supplementary material}

The online version of this article ( https://doi.org/10.1007/s00445-017-1186-9 ) contains supplementary material, which is available to authorized users.

\section{Introduction}

AQ2

Monogenetic volcanoes may form in any type of geological environment (e.g. Connor and Conway 2000; Walker 2000; Németh and Kereszturi 2015). Scoria cones are the most common volcano types on land, yet tuff and tephra rings and cones, as well as maars, are considered to be the second most common volcanic landforms on Earth (e.g. Connor and Conway 2000; Vespermann and Schmincke 2000; De Silva and Lindsay 2015).

In a broad sense, explosive interaction between magma and external water is defined as hydrovolcanism (Sheridan and Wohletz 1983). Hydrovolcanic in this sense includes all the known types of eruptions driven by magma and external water, whether explosive or non-explosive (Kereszturi and Németh 2012; Németh and Kereszturi 2015; Smith and Németh 2017). We here reserve the term phreatomagmatic for those eruptions where magma interacts explosively with groundwater or shallow subsurface water tables or saturated sediments.

Maars are commonly associated with explosive interactions between magma and groundwater during phreatomagmatic eruptions) (e.g. Lorenz 1986; White and Ross 2011; Németh and Kereszturi 2015). Maar volcanoes are also commonly characterised by a volcanic depression with a flat-floored crater that cuts into the syn-eruptive landscape-indicating that the maar crater is a result of a combination of explosive excavation and collapse of the crater floor (Valentine et al. 2015a, b; Lorenz et al. 2017). Maars are normally surrounded by tephra rings that are commonly, but not uniquely, rich in accidental lithic clasts, as the result of the subsurface excavation of their craters and associated diatremes (Graettinger et al. 2014). The volume and nature of accidental lithics in the ejecta rim surrounding a maar will strongly depend on the depth, number, frequency, and the lateral and vertical migration of explosions as scaled analogue experiments have demonstrated recently (Graettinger et al. 2014). Other types of monogenetic landforms that are due to magma-water interaction are tuff rings and tuff cones that, unlike maars that are excavated into the substrate, are built on it (De Silva and Lindsay 2015). Tuff rings refer to a broad flat volcanic edifice, underlain by a shallow diatreme with a small depth-to-diameter ratio near ground level (Cas and Wright 1987; Vespermann and Schmincke 2000; De Silva and Lindsay 2015). On the other hand, tuff cones are associated with thick near-vent deposits that rapidly get thinner outward, having higher profiles and steeper outer slopes (Wohletz and Sheridan 1983; Vespermann and Schmincke 2000; De Silva and Lindsay 2015). $\mathrm{AQ3}$

The complex dynamics of magma-water interaction determines the nature of explosive activity, which is itself characterised by variable energy outputs and different degrees of magmatic or hydromagmatic fragmentation (i.e. Wohletz and Sheridan 1983; Houghton and Hackett 1984; White and Houghton 2000; White and Valentine 2016). Indeed, the interaction between magma and water may range from very mild - with a slow heat exchange that can last hours and releases very little mechanical energy (Schipper et al. 2011) — to extremely violent, detonation-like thermohydraulic explosions (e.g. Zimanowski et al. 1991; Zimanowski et al. 2004; Büttner et al. 2005). In the latter case, more than 30\% of the available thermal system energy (the thermal energy of the batch of melt that interacts with water) is transformed into mechanical energy within a fraction of a millisecond, and about $60 \%$ of this mechanical energy is released as shock waves (Büttner et al. 2005). The efficiency and intensity of these processes are the result of the complex interactions of four independent components that are often internally heterogeneous: magma, magmatic volatiles, external water, and wall rock (De Silva and Lindsay 2015). The type of excavation, crater formation, and componentry of the surrounding ejecta ring will be heavily affected by the depth of the explosions relative to the explosion energy, a quantity known as scaled depth of explosion (Graettinger et al. 2015a, b; Palladino et al. 2015; Sonder et al. 2015; Macorps et al. 2016).

AQ4

AQ5

As a consequence, hydrovolcanic eruptions may show variable degrees of explosivity depending on the way water interacts with the rising or erupting magma; even small-volume eruptions can be highly explosive. This was for example, the case for (1) Ukinrek maars in Alaska with $0.01 \mathrm{~km}^{3}$ of DRE (dense rock equivalent) (Kienle et al. 1980), (2) the Quaternary Auckland Volcanic Field in New Zealand with most eruptive centres having bulk and DRE-corrected eruptive volumes of less than $0.01 \mathrm{~km}^{3}$ (Kereszturi et al. 2013), (3) the Cenozoic Newer Volcanic Province, Australia, with a total erupted tephra at the studied centres of less than $1 \mathrm{~km}^{3}$ (Blaikie et al. 2015) or, for some examples of maars from an ultrapotassic provenance, (4) those of the Sabatini Volcanic District (Roman Province, Central Italy) where bulk volume estimates are up to $1 \mathrm{~km}^{3}$ for the edifices (Sottili et al. 2012). 
Hydrovolcanic eruptions are common in coastal environments, where erupting magma is prone to interaction with seawater in either shallow subaqueous or subaerial settings (Sheridan and Wohletz 1983), as was well-documented at Cheju Island, South Korea (Sohn and Chough 1989; Sohn et al. 2012; Brenna et al. 2015); West Ambrym, Vanuatu (Németh and Cronin 2007, 2011); São Miguel Island, Azores (Zanon et al. 2009); Faial Island, Azores (Machado et al. 1962; Cole et al. 2001); Lanzarote Island, Canary Archipelago (Pedrazzi et al. 2013); Auckland Volcanic Field, New Zealand (Agustín-Flores et al. 2014, 2015a, b); Miyakejima Island, Japan (Aramaki et al. 1986); and Deception Island, Antarctica (Baker et al. 1975; Pedrazzi et al Pedrazzi et al. 2014c . 2014).

Deception Island (DI) is an active Quaternary volcanic caldera of the South Shetlands Archipelago (Antarctica) (Fig. 1a, b). Post-caldera volcanism includes over 30 eruptions during the Holocene, although a considerably higher number of eruptions has been reported (e.g. Orheim 1972). More than 20 eruptions were registered over the past two centuries (Orheim 1972; Roobol 1982; Smellie et al. 2002) including the eruptions of 1967, 1969, and 1970 (Fig. 1c). These eruptions, as well as the 1992, 1999 (Ibáñez et al. 2003), and 2014-2015 (Almendros et al. 2015) unrest episodes, demonstrate that the volcanic system under DI is still very active and that the occurrence of a new eruption is fully plausible.

\section{Fig. 1}

a Location of the South Shetland Archipelago (Google Earth 2016-Image US Geological Survey). b South Shetland Islands Archipelago and location of Deception Island: S, Snow Island; L, Livingston Island; G, Greenwich Island; R, Robert Island; N, Nelson Island; KG, King George Island (modified from Grad et al. 2004). c Simplified geological map of Deception Island (after Smellie et al. 2002; modified from Martí et al. 2013), with the location of the post-caldera explosive vents and recent volcanic activity

AQ7

AQ8
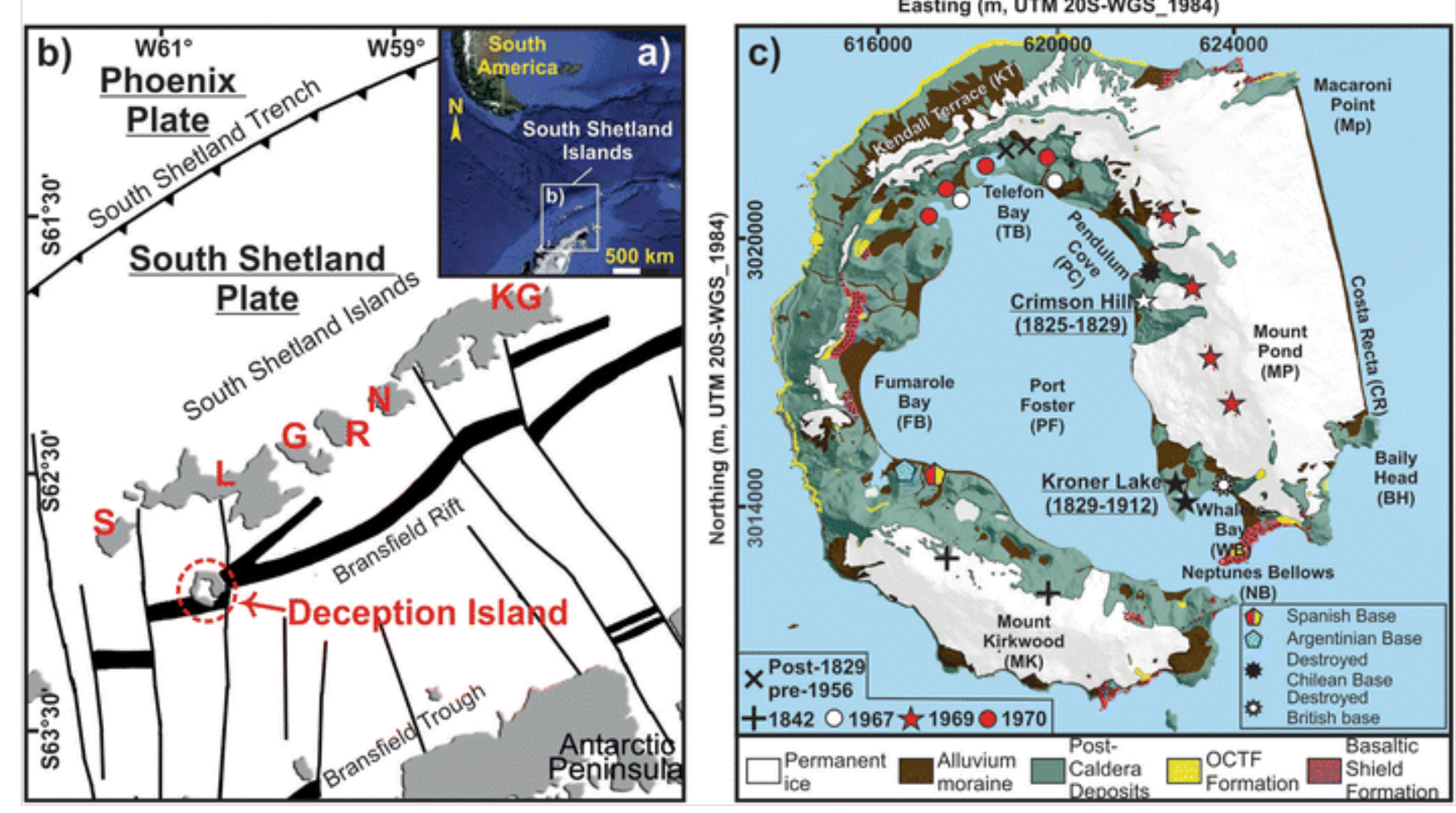

AQ6

Recent post-caldera volcanism is dominated by explosive eruptions driven by magma-water interaction, with the water source being from Port Foster Bay seawater, from the underground aquifer and water from the glaciers (Baker et al. 1975; Smellie 2002; Pedrazzi 2014c et al. 2014). Even small-volume eruptions become highly explosive when located on waterlogged shorelines, or beneath ice caps (Baker et al. 1975; Smellie 2002; Pedrazzi Pedrazzi et al. 2014c et al. 2014). Relevant examples of this are the last three eruptive episodes (1967, 1969, and 1970) that destroyed (or severely damaged) the scientific bases operating on the island (Baker et al. 1975; Roobol 1982; Smellie 2001). Hence, to carry out a more accurate evaluation of volcanic hazards from potential eruptions at DI, we need to assess any violent magma-water interactions promoted by the occurrence of shallow submarine vents, or those located on waterlogged shorelines, or beneath the ice caps.

This issue is socio-economically relevant because Deception and Livingston islands host five research stations and three summer field camps. In addition, Greenwich and King George islands are home to 10 all-year, and 2 temporary, research stations. Moreover, DI is one of the most visited localities in Antarctica with almost 20,000 visitors per year (Bartolini et al. 2014; Bender et al. 2016). 
We have thus conducted a detailed field revision of the historical (1829-1970) hydrovolcanic post-caldera volcanism at DI with the aim of understanding how the location of a potential new eruptive vent can control magma-water interactions, and the related hazards to be expected during a new eruption on the island. The primary purpose of this work is to better comprehend the potential evolution of a future eruption and therefore to improve the volcanic hazard assessment. We focused on the Crimson Hill (dated between 1825 and 1829, Fig. 2), Kroner Lake (dated between 1829 and 1912, Fig. 2), 1967 (Fig. 3), and 1970 (Fig. 4) eruptions as representatives of the entire spectrum of potential hydrovolcanic activity on the island. We also report the 1969 eruption (Fig. 5) in this paper because it exemplifies an important event in the eruptive record at DI due to magma-ice interaction with formation of a jökulhlaup (Smellie 2002).

\section{Fig. 2}

a Simplified geological map of Deception Island, with the Kroner Lake and Crimson Hill stratigraphic logs. Numbers close to stratigraphic logs correspond to sieved samples. b Simplified geological map of Kroner Lake eruption close to Whalers Bay (modified from Roobol 1973)
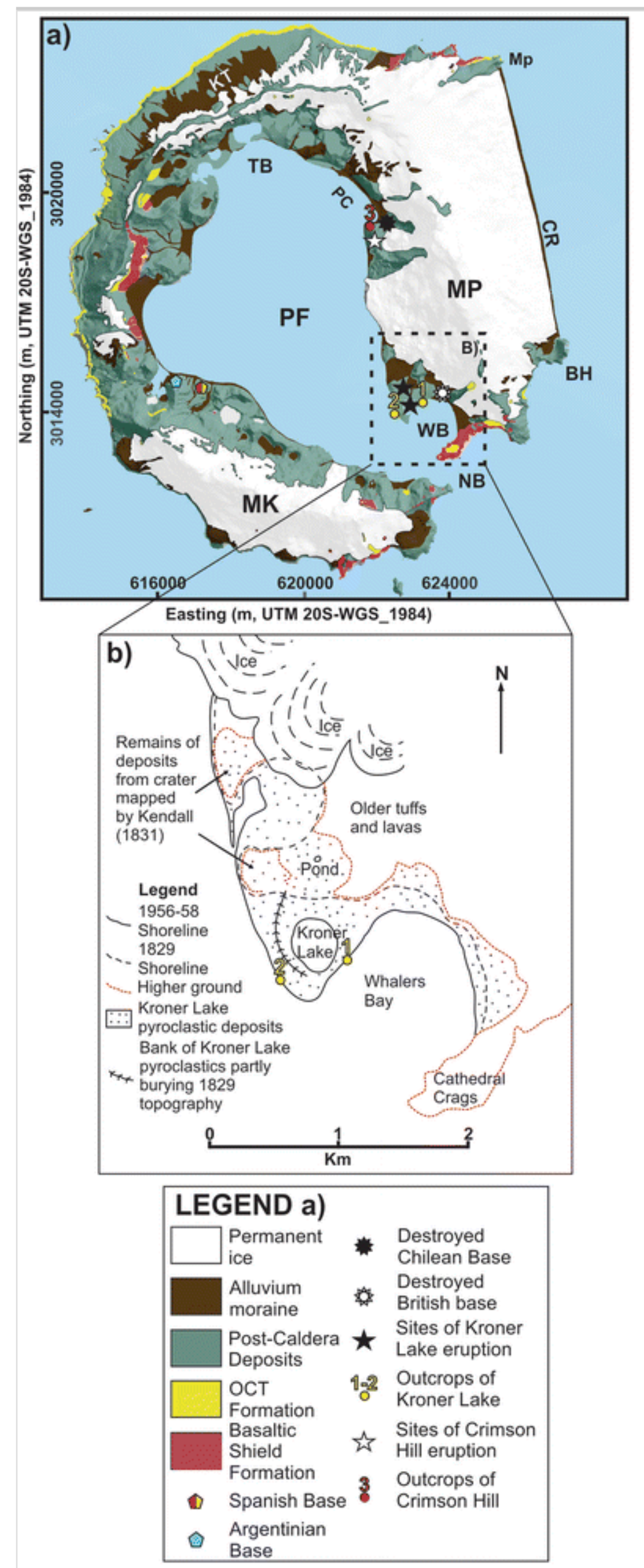

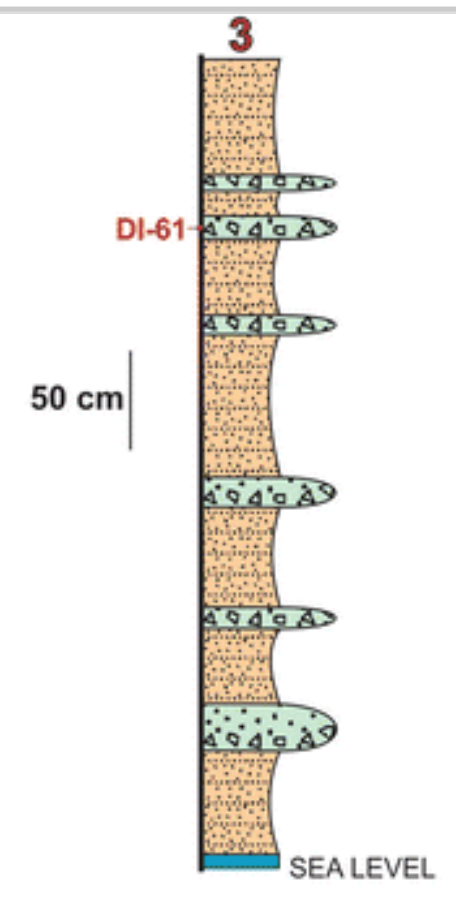

\section{LEGE}

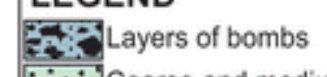

$\because \because{ }^{2}$ Coarse and medium lapilli

Thinly laminated beds of lapill

Fi.jid Fine lapilli and ash

Thinly bedded or laminated lapilli

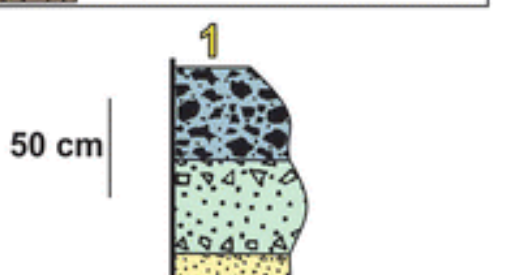

DEI55B-5

DEI55B-4

DEI55B-3

DEI55B-2
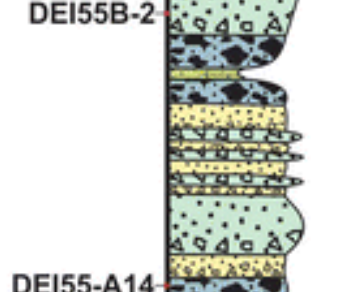

DEI55-A14 $\mathrm{H}$ -

$\begin{array}{lll}\text { DEI55-A13 } & -155-A 12 \\ \text { DEE } & 0\end{array}$

DEI55-A12 11

DEI55-A9 $\because \because \because A 3$

DEI55-A8

DEI55-A7 60 -

DEI55-A6 $\triangle 400$

DEI55-A5

DEI55-A4

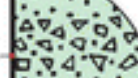

$\therefore$

DEI55-A3

DEI55-A2 $\because 402$

DEI55-A1
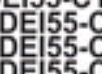
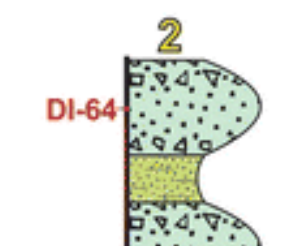

DEI55-D5-

DEI55-D4-

DEI55-D3

DEI55-D2

DEI55-D1

DEI55-C20

DEI55-C18

DEI55-C17

DEI55-C16

DEI55-C15

DEI55-C13

$\because \because \because \because$

EI55-C11
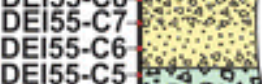

DEI55-C5 454.49

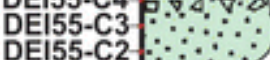

DEEI55-C 21 SO

\section{Fig. 3}

Simplified geological map of Deception Island with a isopach and b isopleth maps of 1967 pyroclastic fall deposits. Stratigraphic logs from the 1967 eruption are also shown (both maps and stratigraphic logs are taken from Baker et al. 1975). Abbreviations in Fig. 3a, b refer to toponyms of Fig. 1c 

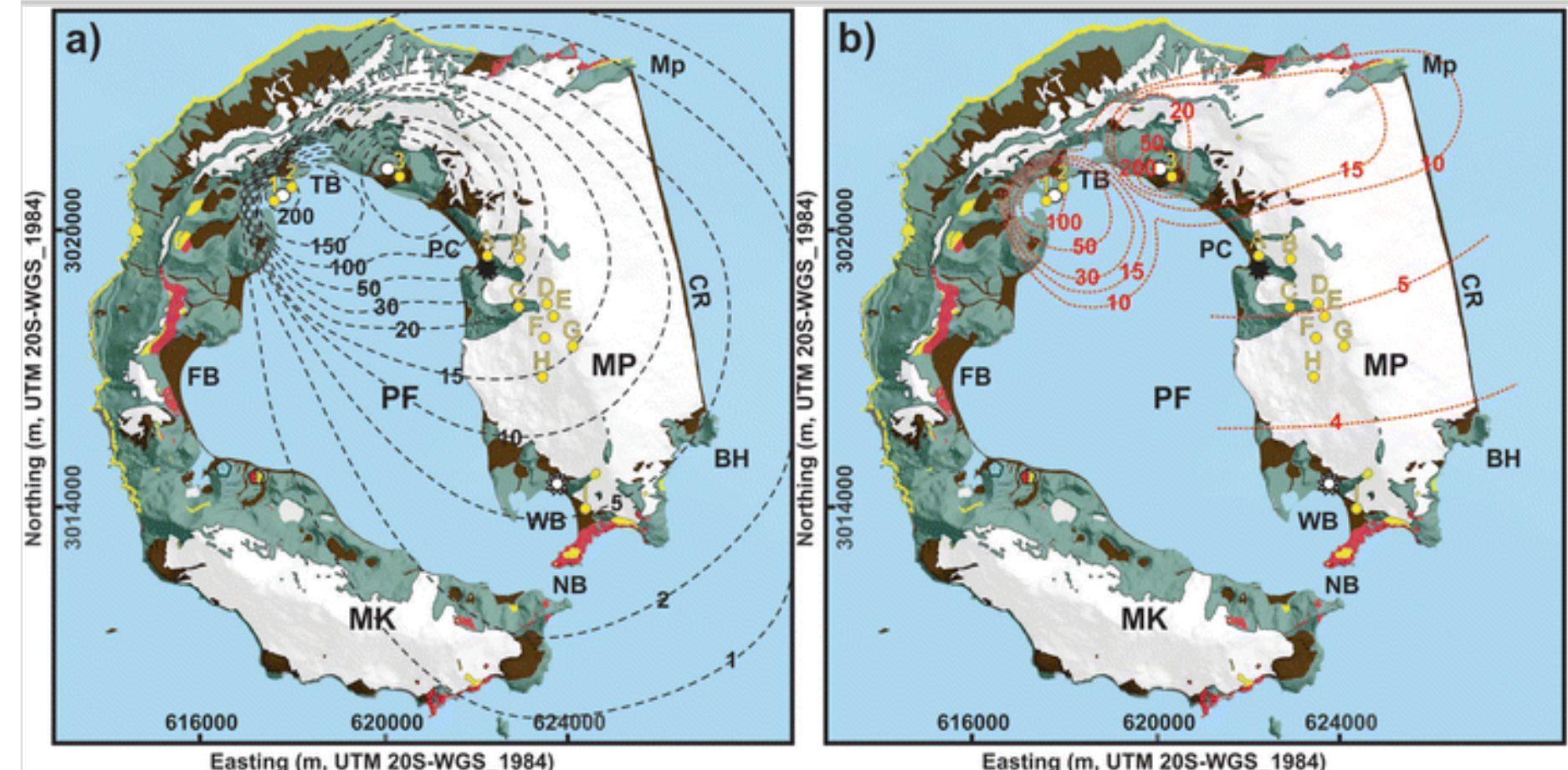

Easting (m, UTM 20S-WGS_1984)

Easting (m, UTM 20S-WGS_1984)

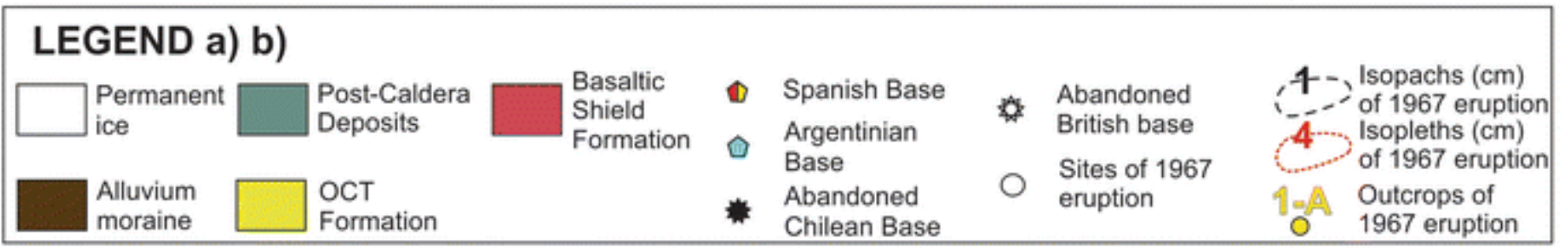
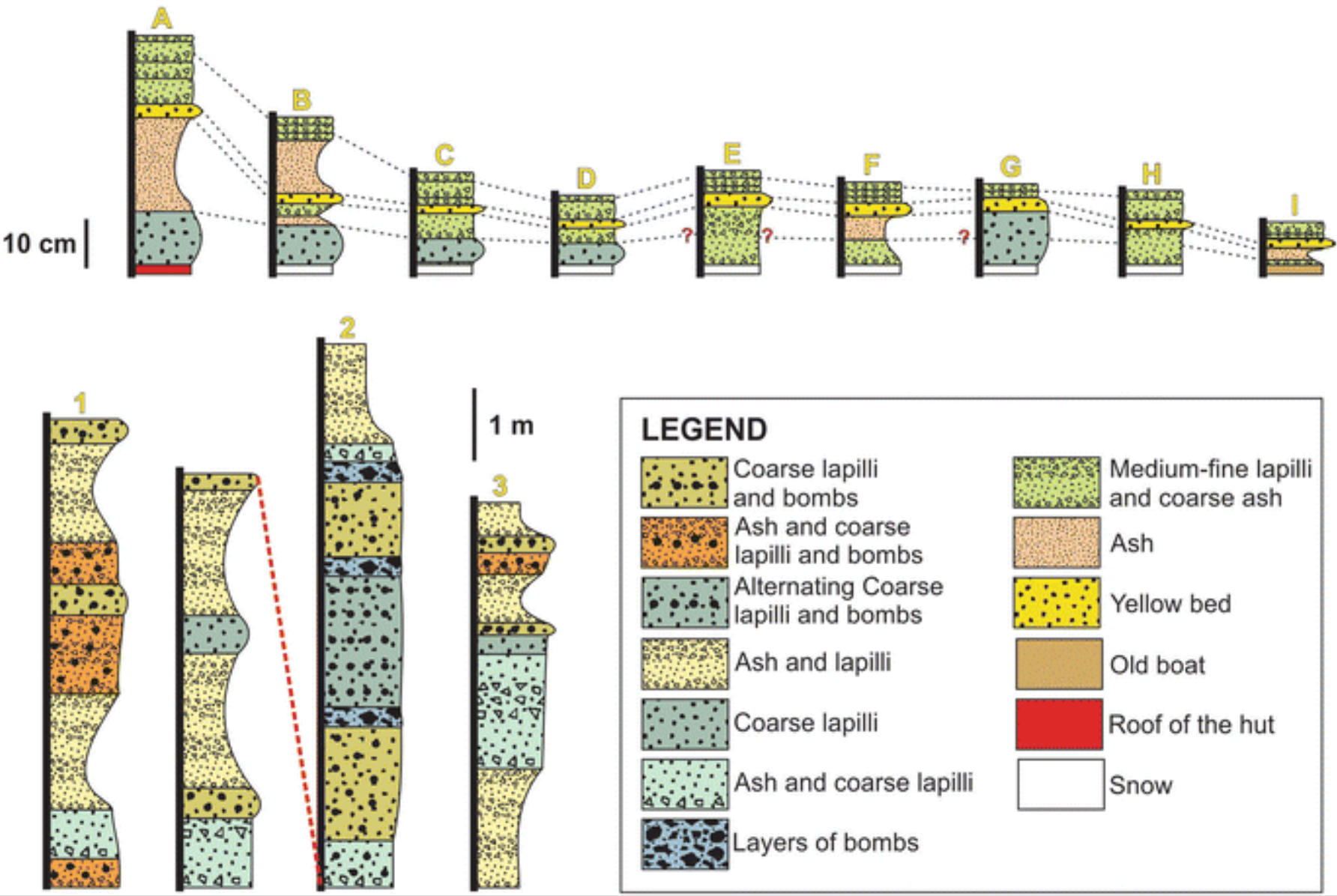

Fig. 4

a Simplified geological map of Deception Island with isopachs on Deception Island from the 1970 eruption. b Isopach and c medium diameter maps of the same eruption in the Bransfield trough are also shown. In the lower part of the figure, stratigraphic logs from the 1970 eruption are shown (both isopach maps are taken from Baker et al. 1975 and medium diameter from Pedrazzi Pedrazzi et al. 2014c et al. 2014) 


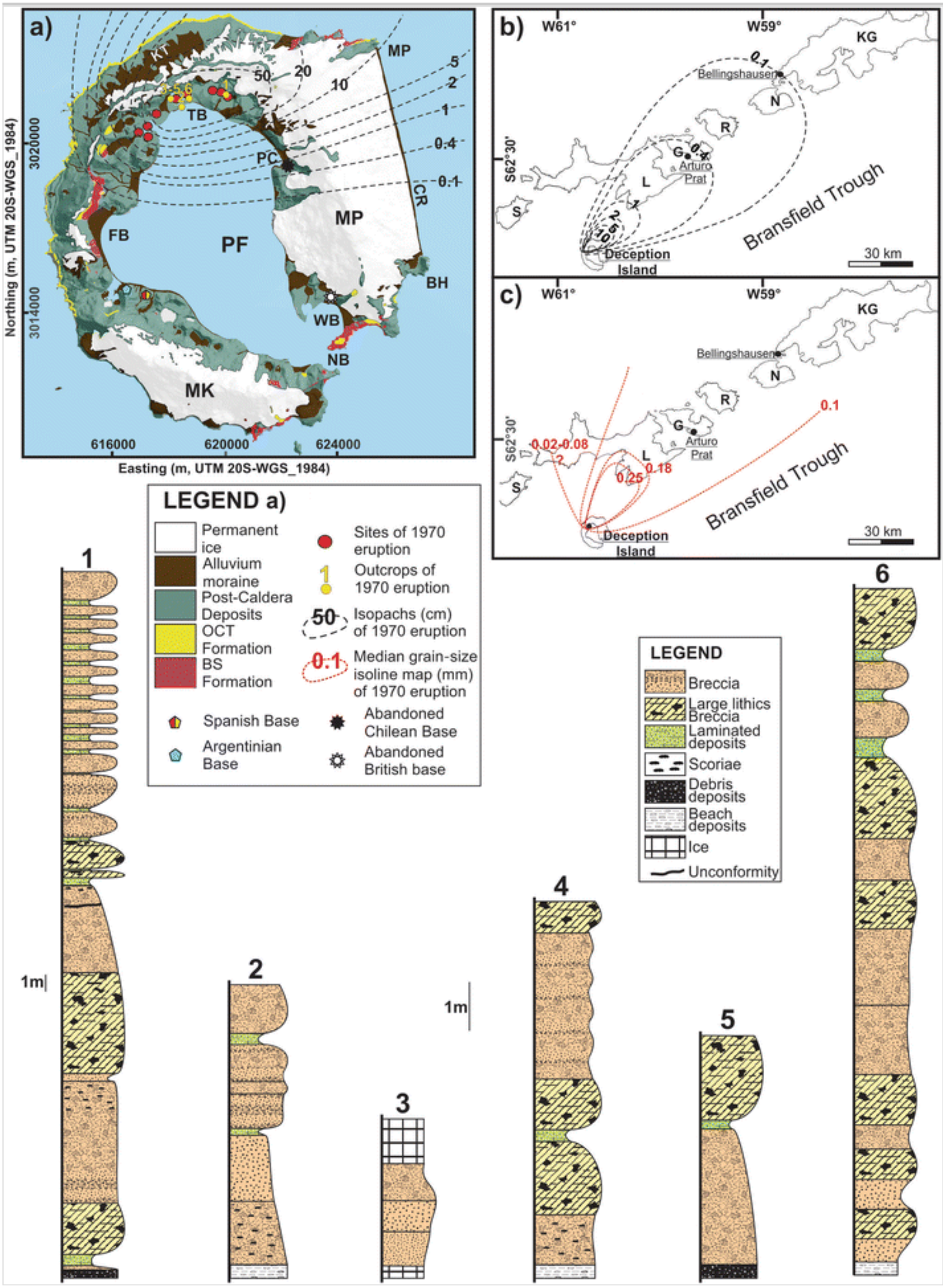

Fig. 5

a Isopach and b isopleth maps of products from the 1969 eruption (taken from Baker et al. 1975). c, d The area of interest of the eruption (from Smellie 2001) 

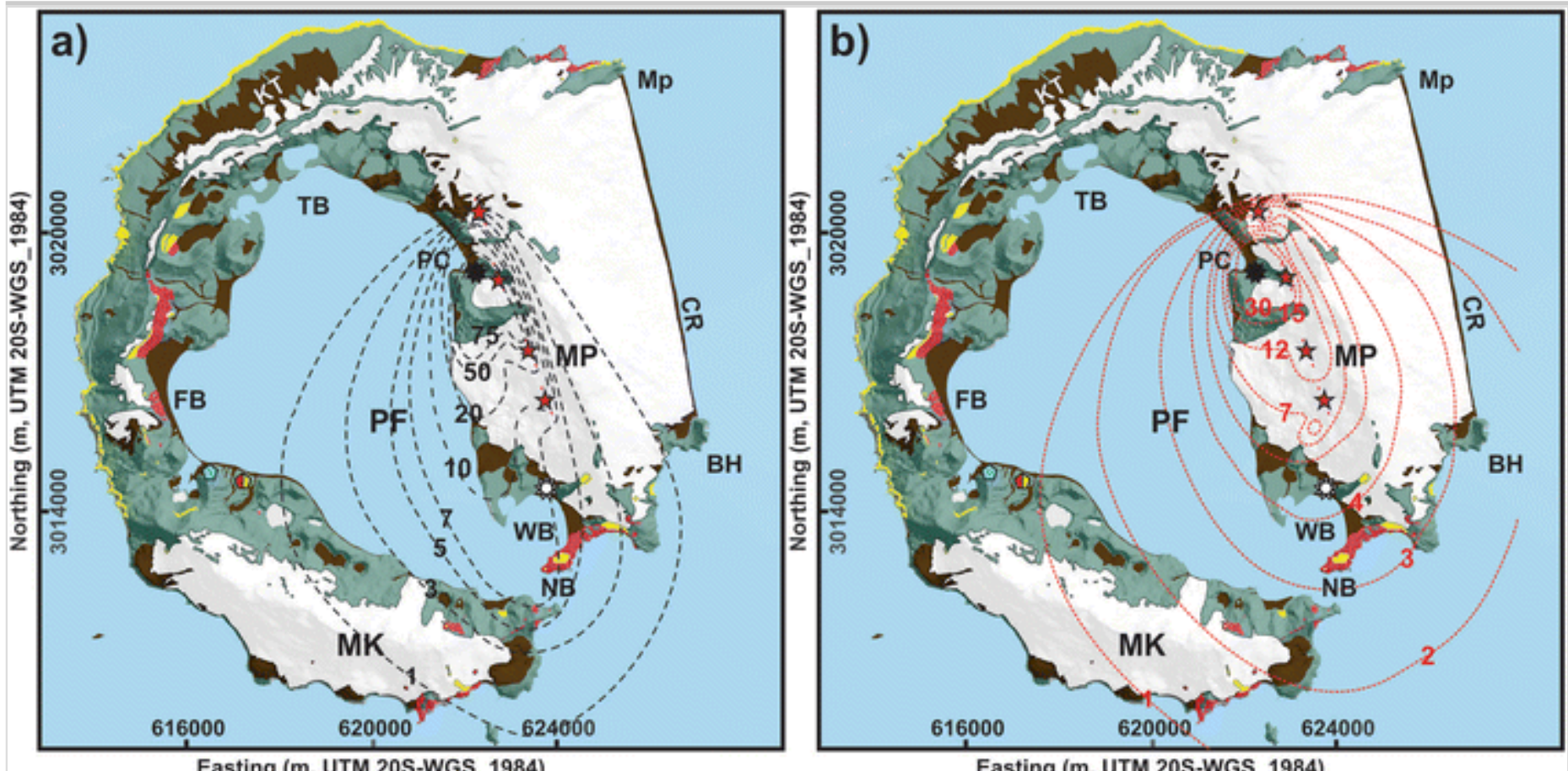

Easting (m, UTM 20S-WGS_1984)

Easting (m, UTM 20S-WGS_1984)

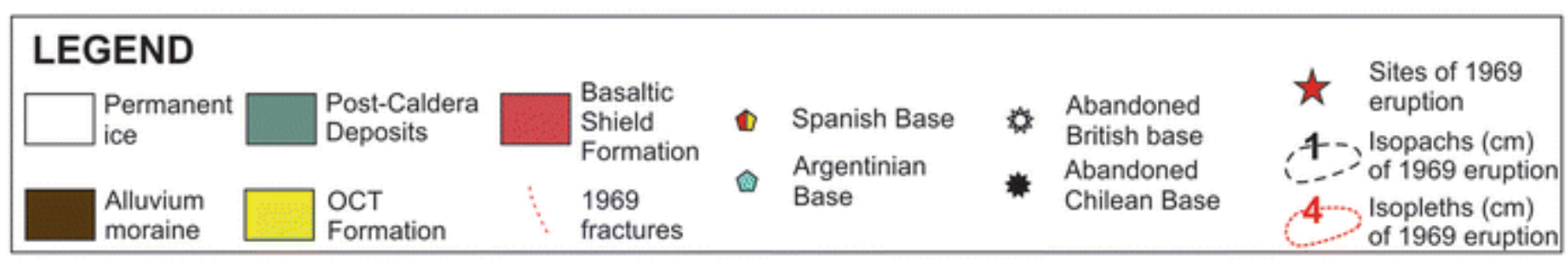
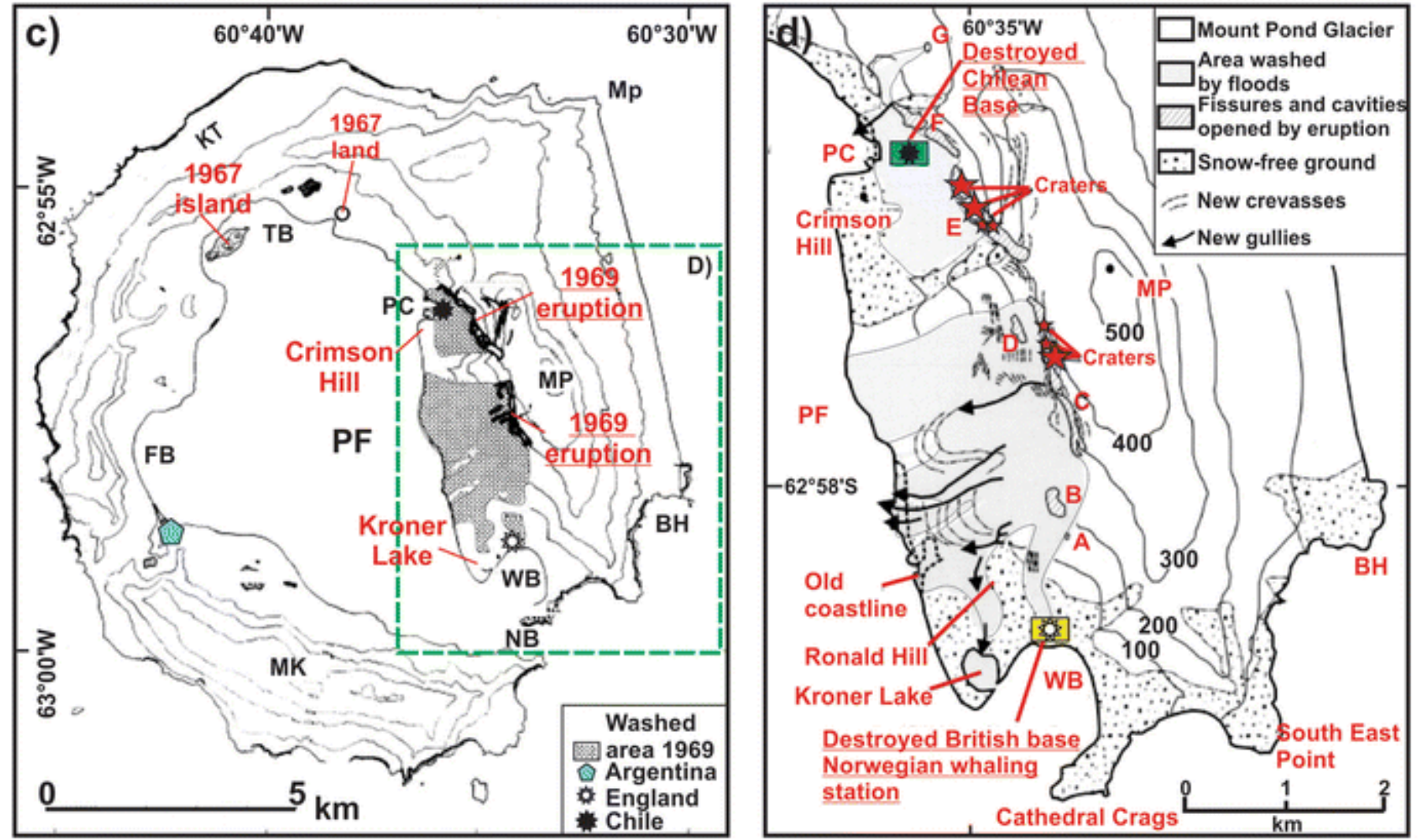

In addition to our own field observations, we have incorporated the existing published data on the above-mentioned eruptions (Orheim 1971c; Roobol 1973, 1980, 1982 Roobol 1982

Roobol, M. J. (1982). The volcanic hazard at Deception Island, South Shetland Islands. British Antarctic Survey Bulletin, 51, $237-245 . \quad$; Baker and McReath 1971, 1975; González-Ferrán et al. 1971; Shultz 1972; Smellie 2002, Smellie et al. 2002). This favours a reinterpretation, or systematic re-description (as in the case of the 1967 eruption), of the available information in light of the modern nomenclature for lithostratigraphic and stratigraphic criteria (e.g. Sohn and Chough 1989; White and Houghton 2006).

AQ9

\section{Geological setting}

Deception Island is the southernmost island in the South Shetland Archipelago, located at the south-western end of the Bransfield Strait (Fig. 1a,b), a marginal young ( $<1.4 \mathrm{Ma}$ ) basin between the Antarctic Peninsula and the South Shetland Islands (Lawver et al. 1995). The basin formed due to the subduction of the Phoenix plate (Eagles 2004) under the Antarctic plate during the late Mesozoic-Cenozoic (Dalziel 1984). The related volcanic ridge has been traditionally interpreted as a Late Cenozoic extensional structure produced by back-arc spreading (Roach 1978; Peccerillo et al. 1991). The Bransfield basin ( $<60 \mathrm{~km}$ wide and $500 \mathrm{~km}$ long) has a characteristic graben structure, with tilted blocks and rotational faults developed under a regime of continental extension (Jeffers and Anderson 1990; Gràcia et al. 1996; Vuan et al. 2005) (Fig. 1b). 
The island consists of a horseshoe-shaped volcanic edifice [younger than $0.75 \mathrm{Ma}$, as determined by Palaeomagnetic studies, and K-Ar age estimations, and conventional mapping (Valencio et al. 1979; Smellie 1988)]. The edifice has a central sea-flooded depression (Port Foster), having a below-sea-level diameter of around 13 km (Smellie 1988; Barclay et al. 2008) (Fig. 1c). The formation of DI is inferred to be related to three main phases: pre-, syn- and post-caldera (Smellie 2001; Martí et al. 2013-Fig. 1c). The first phase corresponds to the construction of multiple coalesced shoaling seamounts and a subaerial volcanic shield that are represented by the Fumarole Bay and Basaltic Shield formations, respectively (Fig. 1c). This stage was followed by syn-caldera eruptions, corresponding to the caldera collapse event (Martí et al. 2013), which deposited the Outer Coast Tuff Formation (OCTF) that buried the preceding geological formations to several tens of meters depth, forming an almost continuous outcrop along the outer part of the island (Fig. 1c). The age of the collapse event remains unclear due to the lack of geochronological data, though recently published paleomagnetic data, in combination with tephra occurrences, suggest that the caldera collapse took place at about 8300 years BC (Oliva-Urcia et al. 2016).

AQ10

The post-caldera phase (Fig. 1c) consists of at least 70 scattered eruptive vents inside the caldera, except one that is found along the structural borders of the caldera itself (Smellie et al. 2002; Martí et al. 2013;). The tephra record from DI and neighbouring islands reveals over 30 post-caldera eruptions during the Holocene, although a considerably higher number of eruptions are thought to have occurred (e.g. Orheim 1972). Historical post-caldera volcanism (1829-1970) on DI involves small-volume basaltic eruptions $\left(<0.1 \mathrm{~km}^{3}\right)$ that are inferred to be monogenetic (using the definitions of Németh and Kereszturi 2015; Smith and Németh 2017), most of them classified as VEI 2 or 3 magnitude events (Volcanic Explosivity Index, Newhall and Self 1982). Nonetheless, the common presence of DI tephras in marine sediments in the Bransfield Strait and Scotia Sea (e.g. Moreton and Smellie 1998; Fretzdorff and Smellie 2003), and in ice cores as far afield as the South Pole (see Smellie 1999), suggests that some post-caldera eruptions may have been much more violent than those which occurred in recent centuries, with larger VEI and eruptive columns over $20 \mathrm{~km}$ high and volumes of extruded material exceeding $0.1 \mathrm{~km}^{3}$.

AQ11

\section{Methods}

Fieldwork was conducted during the austral summer of 2012-2013, allowing us to identify and characterise the stratigraphic features of the different units of the above-mentioned representative historical eruptions. All information collected was digitised and entered into a geodatabase using an open-source GIS framework (QGIS, www.qgis.org ) with (as a cartographic base) a panchromatic orthophoto with a spatial resolution of $0.6 \mathrm{~m}$ per pixel and UTM projection, datum WGS84 - zone 20 South (Torrecillas et al. 2006). The geographical coordinates of the relevant locations (as well as of the stratigraphic sections and sampling points) were recorded using a portable Garmin Dakota-20 GPS to a precision of about $3 \mathrm{~m}$ (Supp Mat 1).

We employed grain size analyses using dry-sieving techniques by weighing 45 representative samples (Supp Mat 2) from the Kroner Lake eruption. Samples were sieved at $1 \varphi$ intervals using sieves with mesh sizes in the range of 32-1/32 mm $(-$ $5 \varphi$ to $5 \varphi)$. The weight percentages of the sieved fractions were calculated and then plotted as cumulative curves to give the grain size distribution. Components of loose pyroclasts were studied through a binocular microscope $(0 \varphi$ to $5 \varphi)$.

Major and trace element analysis of selected scoria samples (Supp Mat 3) were performed by the GeoAnalytical Laboratory at Washington State University using their X-ray fluorescence (XRF) facilities. Concentrations of rare earth elements (REE) were obtained with the inductively coupled plasma mass spectrometer (ICP-MS). With XRF, the relative error of the measurements was under $1 \%$ for both major and trace elements, under 5\% for the REE and under $10 \%$ for the remaining trace elements.

Oxygen isotope analyses were performed at the Servicio General de Análisis de Isótopos Estables (NUCLEUS, University of Salamanca, Spain) on whole-rock powders obtained by laser fluorination (Clayton and Mayeda 1963) on a VG-Isotech SIRA-II dual-inlet mass spectrometer. Results are reported in $\delta^{18} \mathrm{O}$ notation $( \pm 0.2 \%$, $1 \sigma)$ relative to the Vienna Standard Mean Ocean Water (V-SMOW) standard. D/H ratios were determined on a second SIRA-II mass spectrometer, on $\mathrm{H}_{2}$ gas obtained by reduction over hot depleted-U of the water released by induction heating of the samples (Bigeleisen et al. 1952; Godfrey 1962). The yield of evolved gas was used to determine the amount of structural water contained in the sample. Results are reported in $\delta \mathrm{D}$ notation $( \pm 2 \%, 1 \sigma)$ relative to the V-SMOW standard.

\section{Characteristics of the vents and pyroclastic successions}

\section{Magma interaction with seawater and the aquifer}

Crimson Hill 
The Crimson Hill eruption occurred by the current coastline at the southern side of Pendulum Cove (Fig. 2). The first accounts with volcanological details about Crimson Hill are those of the first scientific expedition to the island in 1829 (Roobol 1980). As reported in the same paper, the time of this eruption should have been between 1825 and 1829. No previous morphological description was reported for Crimson Hill, and although the only remained exposed portion of the edifice is the one close to the sea, the original landform should have been roughly circular in shape with a perimeter of about $3.5 \mathrm{~km}$ and a diameter of about $1.3 \mathrm{~km}$ (Table 1). The products of that eruption were covered by post-1829 events, in particular, by the deposits of the 1967 and 1969 eruptions that destroyed the Chilean military base, located at Pendulum Cove (Fig. 2a).

Table 1

General characteristics of Crimson Hill, Kroner Lake, and 1967, 1969, and 1970 eruptions AQ12

\begin{tabular}{|c|c|c|c|c|c|c|c|c|}
\hline Eruption & $\begin{array}{c}\text { Latitude } \\
\text { UTM N } \\
\text { (Zone } \\
20 \mathrm{~S})\end{array}$ & $\begin{array}{l}\text { Longitude } \\
\text { UTM E } \\
\text { (Zone } 20 \\
\text { S) }\end{array}$ & $\begin{array}{l}\text { Characteristics } \\
\text { at time of the } \\
\text { eruption }\end{array}$ & $\begin{array}{c}\text { Characteristics } \\
\text { nowadays }\end{array}$ & $\begin{array}{c}\text { Bulk } \\
\text { Volume } \\
\left(\mathbf{k m}^{3}\right)\end{array}$ & $\begin{array}{l}\text { Deposit } \\
\text { features }\end{array}$ & Interpretation & $\begin{array}{l}\text { Eruption } \\
\text { styles }\end{array}$ \\
\hline $\begin{array}{l}\text { Crimson } \\
\text { Hill }\end{array}$ & 3018964 & 622061 & $\begin{array}{l}\text { Perimeter } \\
3.5 \mathrm{~km} \\
\text { Diameter } \\
1.3 \mathrm{~km}\end{array}$ & $\begin{array}{l}\text { Only a small } \\
\text { portion } \\
\text { outcrops by the } \\
\text { sea, close to } \\
\text { Pendulum Cove }\end{array}$ & - & $\begin{array}{l}\text { Coarse, } \\
\text { massive layers } \\
\text { and thinly } \\
\text { bedded or } \\
\text { laminated } \\
\text { layers. Post- } \\
\text { depositional } \\
\text { palagonitisation }\end{array}$ & $\begin{array}{l}\text { Dilute PDCs } \\
\text { and minor } \\
\text { ballistic blocks } \\
\text { and bombs and } \\
\text { fallout }\end{array}$ & $\begin{array}{l}\text { Magma- } \\
\text { water } \\
\text { interaction } \\
\text { mostly at } \\
\text { sea level } \\
\text { and with a } \\
\text { pressurised } \\
\text { deeper } \\
\text { aquifer }\end{array}$ \\
\hline $\begin{array}{l}\text { Kroner } \\
\text { Lake }\end{array}$ & 3014691 & 622676 & Two vents & $\begin{array}{l}350 \text { by } 300 \mathrm{~m} \\
\text { in diameter } \\
\text { cliffs up to } \\
10 \mathrm{~m} \text { in height }\end{array}$ & 0.005 & $\begin{array}{l}\text { Poorly } \\
\text { vesiculated } \\
\text { scoria bombs } \\
\text { and lapilli } \\
\text { deposits and } \\
\text { subordinate } \\
\text { thinly bedded, } \\
\text { poorly } \\
\text { vesiculated } \\
\text { beds of scoria } \\
\text { of fine lapilli } \\
\text { size }\end{array}$ & $\begin{array}{l}\text { Fallout } \\
\text { deposits with } \\
\text { subordinate } \\
\text { dilute PDCs }\end{array}$ & $\begin{array}{l}\text { Interaction } \\
\text { with } \\
\text { shallow } \\
\text { seawater } \\
\text { very close } \\
\text { to the } \\
\text { coastline }\end{array}$ \\
\hline $\begin{array}{l}1967 \\
\text { "island" }\end{array}$ & 3020706 & 617981 & $\begin{array}{l}\text { Three } \\
\text { overlapping } \\
\text { craters } 934 \mathrm{~m} \\
\text { by } 366 \mathrm{~m} \\
62 \mathrm{~m} \text { a.s.1. }\end{array}$ & $\begin{array}{l}\text { Three } \\
\text { overlapping } \\
\text { craters } 600 \mathrm{~m} \\
\text { by } 240 \mathrm{~m}\end{array}$ & \multirow[b]{2}{*}{$\begin{array}{l}0.05 \\
\text { (tot) }\end{array}$} & \multirow{2}{*}{$\begin{array}{l}\text { Ash and lapilli } \\
\text { beds with } \\
\text { bombs and } \\
\text { subordinate } \\
\text { beds of very } \\
\text { coarse lapilli } \\
\text { and bombs }\end{array}$} & \multirow{2}{*}{$\begin{array}{l}\text { Fallout, } \\
\text { ballistic blocks } \\
\text { and bombs, } \\
\text { and } \\
\text { subordinated } \\
\text { dilute PDCs }\end{array}$} & $\begin{array}{l}\text { Interaction } \\
\text { with } \\
\text { seawater }\end{array}$ \\
\hline $\begin{array}{l}1967 \\
\text { "land" }\end{array}$ & 3021091 & 620356 & $\begin{array}{l}\text { Two distinct } \\
\text { vents in a much } \\
\text { older crater } \\
\text { measuring } \\
\text { about } 1100 \mathrm{~m} \\
\text { by } 800 \mathrm{~m}\end{array}$ & $\begin{array}{l}\text { Area of about } \\
450 \mathrm{~m} \text { by } 450 \mathrm{~m}\end{array}$ & & & & $\begin{array}{l}\text { Magma } \\
\text { interaction } \\
\text { with } \\
\text { water- } \\
\text { saturated } \\
\text { or icy } \\
\text { substrate }\end{array}$ \\
\hline 1969 & 3020158 & 622521 & \multirow{4}{*}{$\begin{array}{l}\text { Three fissures } \\
500-1000 \mathrm{~m} \text { in } \\
\text { length, } 100- \\
150 \mathrm{~m} \text { in width, } \\
\text { and } 70-100 \mathrm{~m} \\
\text { deep } \\
\text { Cones were not } \\
\text { visible outside }\end{array}$} & \multirow{4}{*}{$\begin{array}{l}\text { Vents covered } \\
\text { by ice at Mt. } \\
\text { Kirkwood }\end{array}$} & \multirow{4}{*}{$\begin{array}{l}0.03 \\
\text { (tot) }\end{array}$} & \multirow{4}{*}{$\begin{array}{l}\text { Widespread } \\
\text { flood of } \\
\text { meltwater. } \\
\text { Unstratified } \\
\text { bomb and } \\
\text { scoria deposits } \\
\text { characterise the } \\
\text { highest } \\
\text { exposures } \\
\text { Lowest } \\
\text { exposures } \\
\text { comprise } \\
\text { deposits mainly } \\
\text { formed by } \\
\text { bombs and } \\
\text { finely vesicular } \\
\text { coarse scoriae }\end{array}$} & \multirow{4}{*}{$\begin{array}{l}\text { Fallout, } \\
\text { ballistic blocks } \\
\text { and bombs }\end{array}$} & \multirow{4}{*}{$\begin{array}{l}\text { Magma- } \\
\text { snow/ice } \\
\text { interaction }\end{array}$} \\
\hline 1969 & 3018608 & 622998 & & & & & & \\
\hline 1969 & 3017062 & 623311 & & & & & & \\
\hline 1969 & 3016057 & 623729 & & & & & & \\
\hline $\begin{array}{l}1970 \\
\text { "island" } \\
\text { Lago } \\
\text { Escondido }\end{array}$ & 3021469 & 618643 & $\begin{array}{l}\text { Diameter } 770 \\
\text { by } 300 \text { and } \\
450 \mathrm{~m} \\
\text { (probably a } \\
\text { double crater) }\end{array}$ & $\begin{array}{l}1 \text { vent } \\
\text { (probably a } \\
\text { double crater) } \\
750 \text { by } 340 \text { and } \\
460\end{array}$ & 0.1 & $\begin{array}{l}\text { Breccia beds } \\
\text { with beds of } \\
\text { poorly sorted } \\
\text { coarse lapilli } \\
\text { showing weak } \\
\text { lamination. } \\
\text { Deposits } \\
\text { covered by ice } \\
\text { and snow }\end{array}$ & $\begin{array}{l}\text { Fallout, } \\
\text { ballistic blocks } \\
\text { and bombs, } \\
\text { and } \\
\text { subordinated } \\
\text { dilute PDCs }\end{array}$ & $\begin{array}{l}\text { Interaction } \\
\text { with } \\
\text { seawater }\end{array}$ \\
\hline
\end{tabular}




\begin{tabular}{|c|c|c|c|c|c|c|c|c|}
\hline Eruption & $\begin{array}{l}\text { Latitude } \\
\text { UTM N } \\
\text { (Zone } \\
\text { 20 S) }\end{array}$ & $\begin{array}{l}\text { Longitude } \\
\text { UTM E } \\
\text { (Zone } 20 \\
\text { S) }\end{array}$ & $\begin{array}{c}\text { Characteristics } \\
\text { at time of the } \\
\text { eruption }\end{array}$ & $\begin{array}{c}\text { Characteristics } \\
\text { nowadays }\end{array}$ & $\begin{array}{c}\text { Bulk } \\
\text { Volume } \\
(\mathbf{k m})\end{array}$ & $\begin{array}{l}\text { Deposit } \\
\text { features }\end{array}$ & Interpretation & $\begin{array}{l}\text { Eruption } \\
\text { styles }\end{array}$ \\
\hline $\begin{array}{l}1970 \\
\text { "island" }\end{array}$ & 3020936 & 617834 & $\begin{array}{l}\text { Depression } \\
\text { occupied by a } \\
\text { lake whose } \\
\text { surface is only } \\
\text { about } 2 \text { m a.s.1. }\end{array}$ & 1 vent & & $\begin{array}{l}\text { Deposit } \\
\text { covered by ice } \\
\text { and snow }\end{array}$ & - & - \\
\hline $\begin{array}{l}1970 \\
\text { "island" }\end{array}$ & 3020374 & 617451 & $\begin{array}{l}\text { Three craters } \\
\text { with maximum } \\
\text { diameters of } \\
250,300 \text {, and } \\
450 \mathrm{~m} \text {, cliffs } \\
\text { that reach } 20- \\
25 \mathrm{~m} \text { in height }\end{array}$ & 3 vents & & $\begin{array}{l}\text { Deposit } \\
\text { covered by ice } \\
\text { and snow }\end{array}$ & - & - \\
\hline $\begin{array}{l}1970 \\
\text { "land", }\end{array}$ & 3021515 & 620229 & $\begin{array}{l}7 \text { vents, rim } \\
\text { diameters range } \\
\text { from } 50 \text { to } \\
300 \mathrm{~m} \\
\text { maximum depth } \\
\text { is about } 150 \mathrm{~m}\end{array}$ & $\begin{array}{l}6 \text { vents (one } \\
\text { eroded by a by } \\
\text { the island's } \\
\text { glacier) }\end{array}$ & & $\begin{array}{l}\text { Lower part } \\
\text { breccia and } \\
\text { bomb beds, } \\
\text { upper part fine } \\
\text { and coarse } \\
\text { lapilli beds } \\
\text { with planar } \\
\text { stratification }\end{array}$ & $\begin{array}{l}\text { Fallout, } \\
\text { ballistic blocks } \\
\text { and bombs, } \\
\text { and } \\
\text { subordinated } \\
\text { dilute PDCs }\end{array}$ & $\begin{array}{l}\text { Magma } \\
\text { interaction } \\
\text { with } \\
\text { water- } \\
\text { saturated } \\
\text { or icy } \\
\text { substrate }\end{array}$ \\
\hline
\end{tabular}

The Crimson Hill deposits that are exposed at Pendulum Cove on the western side of the volcano are affected by postdepositional palagonitisation. The sequence is poorly preserved, and it was possible to document a broad reconstruction (stratigraphic $\log 3$, Fig. 2), which is characterised by a succession of bed-couplets consisting of coarse, massive, relatively fine-depleted layers of poorly sorted, lithic-rich thin beds $(3-10 \mathrm{~cm})$ with poorly vesiculated scoria lapilli of red and black colour. These are overlain by thinly bedded-to-laminated layers (Fig. 6b). The maximum observed size for accidental lithic clasts (andesitic lavas and clasts belonging to the OCTF formation) and scoriae is $2-3 \mathrm{~cm}$. Lithic-rich well-sorted coarse medium or thick $(10-100 \mathrm{~cm})$ beds of poorly vesicular scoria with a maximum clast size of around 5-6 $\mathrm{cm}$ are also identified (Fig. 6c). Ballistic fragments up to $30-40 \mathrm{~cm}$ in diameter can also be found in the sequence with evidence of impact sags (Fig. 6b, c). Due to the strong palagonitisation of the deposits, we could estimate (in the field) only a rough percentage of lithic clasts (ignimbrites of the OCTF and dacitic lavas from the BSF), which were around less than $10 \%$ by visual estimates. The presence of snow, ice, and an extensive coverage of 1969 eruption products hindered the identification of distal outcrops.

\section{Fig. 6}

a Orthophotomap of Deception Island (Torrecillas et al. 2006) with the location of the field photographs of the same figure. b Crimson Hill sequence with laminated layers and lithics of lava (BSF, Basaltic Shield Formation) and ignimbrite (OCTF, Outer Coast Tuff Formation) and $\mathbf{c}$ detail of the same sequence; measuring tape as scale is about $6 \mathrm{~cm}$ long. $\mathbf{d}$ Kroner Lake. $\mathbf{e}$ Outcrop at Kroner Lake with the main sequence of lapilli and ash with some laminated beds. $f$ Detail of Fig. 6e with a scoria bed. $\mathbf{g} 1967$ edifice "island" just after the eruption (modified from Smellie et al. 2002) and $\mathbf{h}$ nowadays. i 1967 edifice "land" just after the eruption (modified from Smellie et al. 2002) j lithics at 1967 outcrop. k 1967 and 1970 "land" craters. I main stratigraphic sequence at 1970 edifice land with very thick breccia beds, a stratigraphic unconformity in the middle and the upper part with medium-thick beds with weak lamination. m Lago Escondido (1970 "island" eruption). n Stratigraphic sequence at Lago Escondido with breccia beds containing bombs and lithics and crude stratification with scoria bombs. o 1969 subglacial eruption (modified from Smellie et al. 2002)

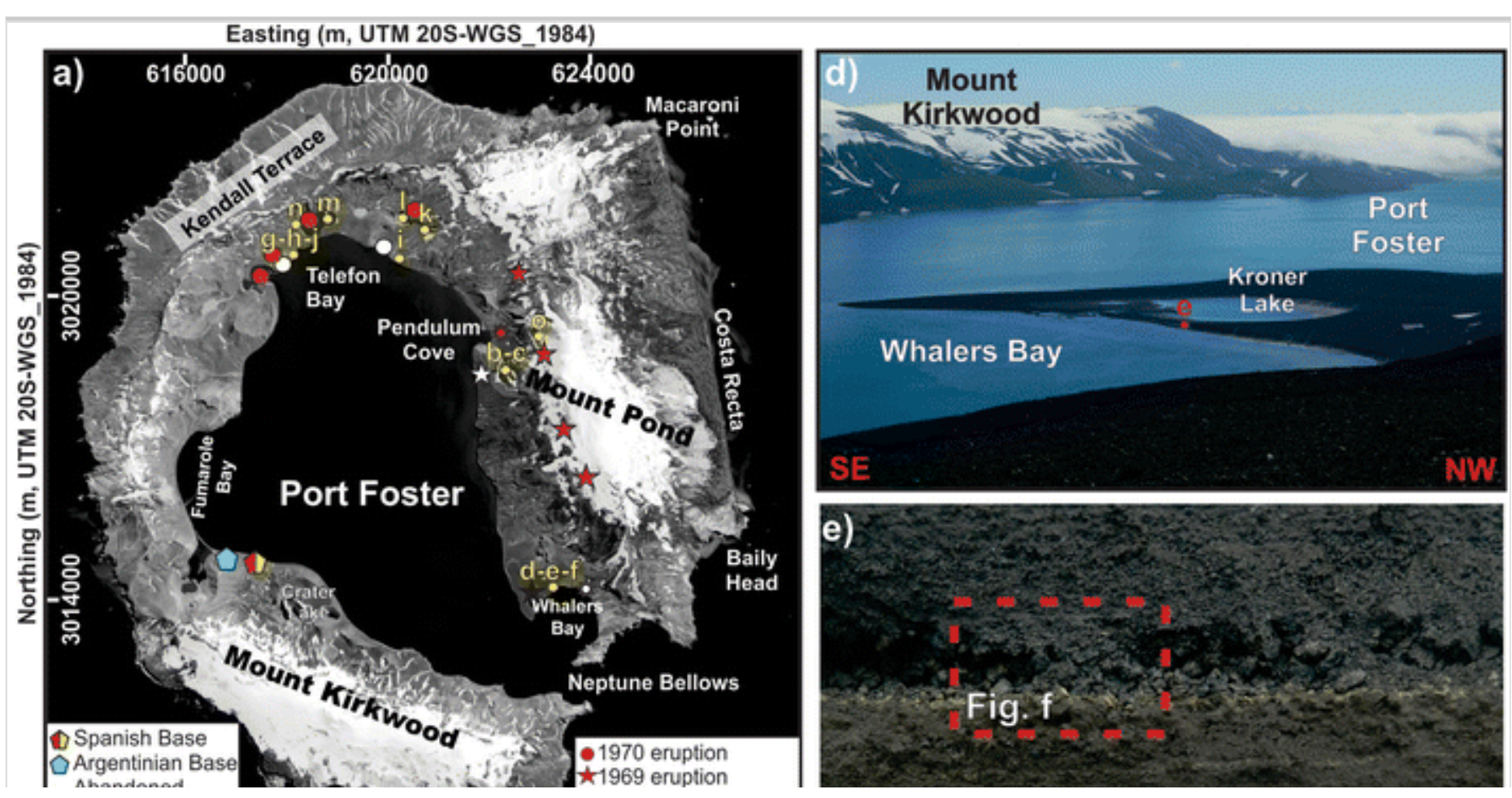



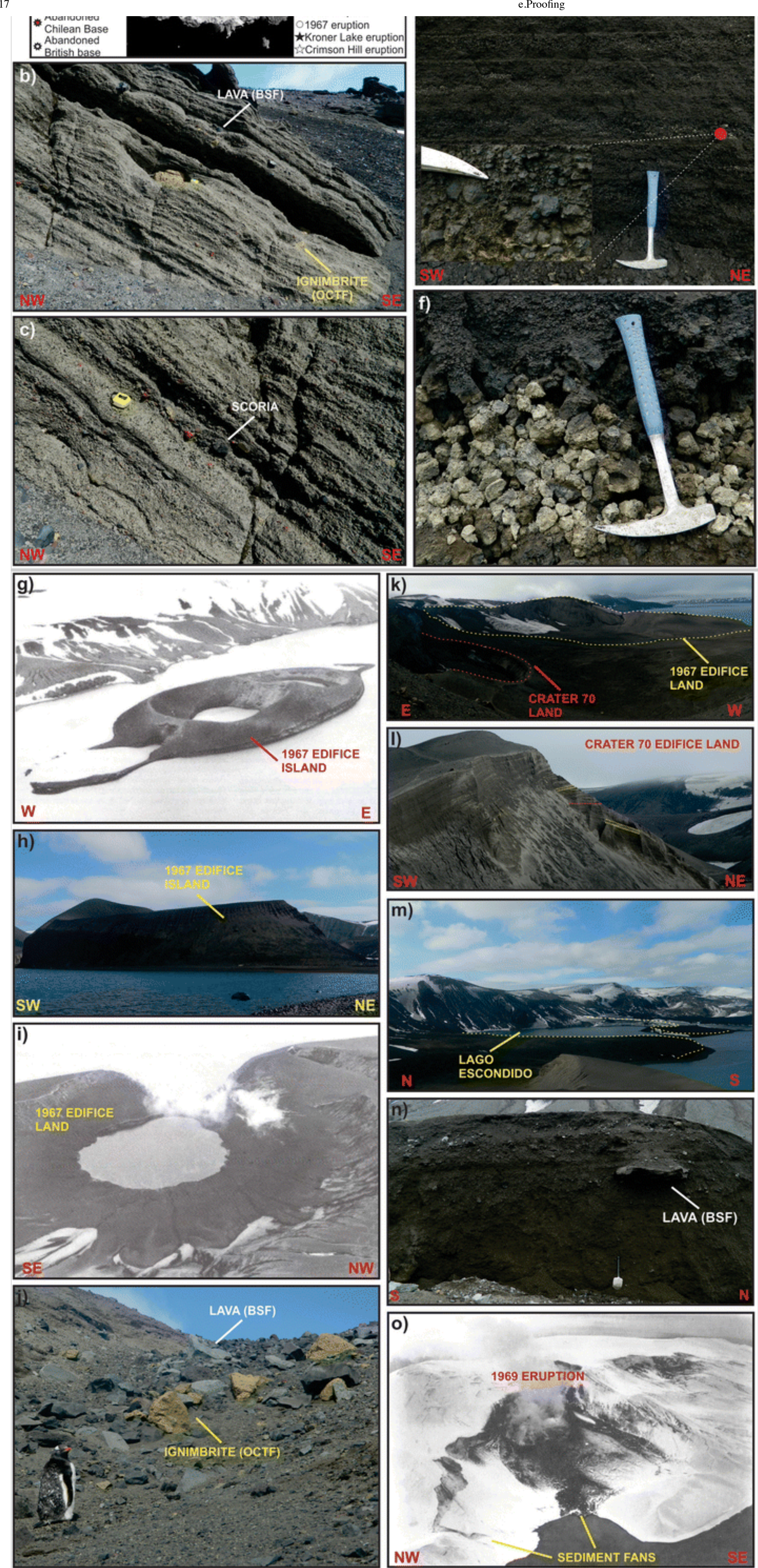


\section{Kroner Lake}

The Kroner Lake eruption (Figs. 2 and 6d-f) occurred in shallow seawater (0-20 b.s.1.) at Whalers Bay, leading to the formation of two vents: Kroner Lake and the depression immediately to the North that was blanketed by later material, leaving only the two depressions with a small pond in the centre (Fig. 2b). These deposits are characterised by a sequence of poorly vesiculated scoria bombs and lapilli with normal and reverse grading, containing subordinate well-sorted wellvesiculated bombs, scoriae deposits, and thinly bedded beds of poorly vesiculated scoria of fine lapilli size. The eruption was briefly described by Roobol (1973), who compared the 1829 topographic map (Kendal 1831) and the 1956 air photographs and topographic maps (Hawkes 1961) of DI at the north shore of Whalers Bay (Fig. 2b). No additional information is available about the general morphological features of Kroner Lake craters right after the eruption. The entire area was washed out by the 1969 jökulhlaup (Smellie 2002); the northern pond was infilled while Kroner Lake was breached on its southern side. The present-day Kroner Lake crater has an almost circular shape, $350 \mathrm{~m}$ by $300 \mathrm{~m}$ in diameter, and is delimited by near-vertical cliffs up to $10 \mathrm{~m}$ in height. A minimum bulk volume of erupted tephra $\left(0.005 \mathrm{~km}^{3}\right)$ can be estimated based on the cartography of Roobol (1973) and on data from the last field survey (20122013) (Table 1).

Only proximal outcrops are exposed and two stratigraphic logs were described at the western and eastern side of the vent. The sequence at stratigraphic log 1 (Fig. 2, eastern side of the crater) is mainly characterised by poorly sorted medium (10$30 \mathrm{~cm}$ thick) and thick (30-100 cm thick) beds of poorly vesicular juvenile coarse, medium, and fine lapilli and ash with subordinate poorly sorted medium (10-30 cm thick) beds with planar stratification of poorly vesicular juvenile fine lapilli (Fig. 6e). Highly vesicular scoria bomb enrichment is observed in some beds in the upper part of the sequence (Fig. 6e, f).

The sequence is slightly different on the western side (stratigraphic $\log 2$, Fig. 2) where the presence of scoria beds and planar stratified beds is missing except in the uppermost part of the sequence. No accidental lithic clasts were recognised in the whole sequence.

\section{The 1967 eruption}

According to Baker et al. (1975), earthquakes preceded the eruption in late April 1967. Further tremors were experienced in November and these increased in frequency and intensity, culminating in the eruption, which began on 4 December 1967. A column of black ash and vapour was observed breaking through the partial ice cover of Telefon Bay, expanding rapidly to reach at first a height of $2500 \mathrm{~m}$, and then rising up to $10,000 \mathrm{~m}$.

The eruption led to the formation of a new island (the so-called "island" centres) that was elongated in a north-east to south-west direction consisting of three overlapping pyroclastic cones with water-filled craters (Fig. 6g, h). It had maximum dimensions of $934 \mathrm{~m}$ by $366 \mathrm{~m}$ and reached $62 \mathrm{~m}$ a.s.l. (Table 1). The subsequent activity of 1970 in the same area led to the partial destruction of the centres of the "island" that were almost cut into two sections longitudinally by this following eruption. The south-eastern half is today visible and the total dimensions are $600 \mathrm{~m}$ by $240 \mathrm{~m}$ (Table 1). The 1967 eruption also lead to the formation of a "land" centre (Fig. 6i), which was roughly circular and situated $2 \mathrm{~km}$ east of the new island on the shore of Port Foster between Telefon Bay and Pendulum Cove (Fig. 3). Two distinct vents were active at the time within a much older crater measuring about $1100 \mathrm{~m}$ by $800 \mathrm{~m}$ (Baker et al. 1975). The cone's primary morphology is still preserved, close to the more recent craters of the 1970 eruption (Table 1).

The 3-day-long eruption (3-6 of December 1967; Baker et al. 1975) produced lithic-rich (ignimbrites and dacitic lavas) bombs, blocks, lapilli, and ash deposits (Fig. 6j; Baker et al. 1975). The south-eastward elongation of the measured isopachs of the tephra distribution (Fig. 3a) indicates a dominant north-westerly wind, consistent with the observations made on 4 December (Baker et al. 1975). However, in the declining stages of activity, there is evidence that the wind changed toward the south, as suggested by the distribution of the final ash deposits (Baker et al. 1975). The isopleth map (Fig. 3b) differs from the isopach map (Fig. 3a) in showing an eastward elongation; this is probably because isopachs incorporate data for the entire eruption, whereas the size-distribution data are compiled essentially from fragments at the surface, representing the final stages of activity (Baker et al. 1975).

Proximal and distal outcrops were described in Baker et al. (1975) and are here reinterpreted in the light of the current nomenclature (Sohn and Chough 1989; White and Houghton 2006). Stratigraphic logs 1-3 (Fig. 3) obtained at craters I, II, and III of the new island and at the land centre show a lithic-rich (ignimbrites and dacitic lavas; by field observation around $10-30 \%)$ sequence that is characterised by medium (10-30 cm thick beds) to very thick ( $>100 \mathrm{~cm}$ thick beds) of poorly vesicular ash and lapilli to coarse lapilli and bombs, with only a few beds (from medium to very thick) of very coarse lapilli and bombs. On the basis of common stratigraphy architecture, lithology, and lithofacies distribution, distal outcrops (stratigraphic logs A-I; Fig. 3) show a stratigraphic correlation of the proximal 1967 pyroclastic deposits. Baker et al. (1975) estimated a minimum bulk volume of $0.05 \mathrm{~km}^{3}$ for the 1967 erupted material, based on their isopach map (Fig. 3a). 
The 1970 eruption (Fig. 4) was first reported in Baker et al. (1975), although with no stratigraphic description of the deposits. More recently, Pedrazzi Pedrazzi et al. 2014c et al. (2014) described in detail, especially the stratigraphic sequence and evolution of the eruption. As opposed to the 1967 and 1969 events, the 1970 episode occurred during the southern winter, when DI was unoccupied, so there were no eyewitnesses to the event. However, similar to the 1967 and 1969 episodes, seismic activity was reported before the eruption (Baker et al. 1975).

The craters from 1970 are located between Goddard Hill and Cross Hill, at the foot of the caldera wall in the northern part of DI (Fig. 4a). This last eruption was characterised by 13 "land" and "island" vents (Baker et al. 1975; Pedrazzi et al.

Pedrazzi et al. 2014c 2014). The former ones consisted of seven conical edifices located at the foot of Goddard Hill and are aligned roughly NW-SE. Their rim diameters range from about 50 to $300 \mathrm{~m}$ with a maximum depth of about $150 \mathrm{~m}$ (Table 1). Currently, the original morphology of each crater is well preserved. However, the easternmost crater previously described in Baker et al. (1975) has already been eroded away by the island's glacier. The "island" centres (with six vents) formed at the foot of the exposed part of the caldera wall with craters having near-vertical sides with cliffs that reached 20$25 \mathrm{~m}$ in height. "Island" centres resulted in the formation of a new strip of land about $1700 \mathrm{~m}$ long by $400 \mathrm{~m}$ wide (Table 1). At present, 1970 "island" craters still preserve their original morphology (Table 1).

The stratigraphic logs on the section exposed in the crater walls show differences to sections recorded from the exposed rim successions (Fig. 4). At the "land" craters (Fig. 6 k, 1), the sequence is mainly characterised by ignimbritic lithic-rich, poorly sorted, medium-thick $(10-30 \mathrm{~cm})$ beds of poorly vesicular lapilli at the base and capped by very thick $(>100 \mathrm{~cm})$ bomb-rich beds, alternating with massive, poorly sorted, lithic-rich (mainly dacitic lavas), very thick $(>100 \mathrm{~cm})$ breccia beds. The upper part is characterised by a continuous alternation of thick $(30-100 \mathrm{~cm})$ to very thick $(>100 \mathrm{~cm})$, coarse well-sorted lapilli-sized breccia beds with accidental (mainly dacitic lavas) lithic fragments and non-vesiculated juvenile scoria and medium-thick $(10-30 \mathrm{~cm})$ fine and coarse poorly vesicular lapilli beds with planar stratification. Small variations in the amount of lithic components can be observed at "land" craters with content ranges around $10 \%$.

At the "island" centres (Figs. 4 and $6 \mathrm{~m}$ ), the succession is mainly characterised by very thick ( $>100 \mathrm{~cm})$, poorly sorted, lithic-rich (ignimbrites and mainly dacitic lava clasts) breccia beds with some medium thickness $(10-30 \mathrm{~cm})$ beds with coarse lamination and poorly sorted coarse lapilli. Crude stratification is shown in some of the deposits as well as enrichment of scoria bombs and accidental lithics (Fig. 6n). This group of craters shows a general increase in the amount of lithic components up to $20-30 \%$ based on visual estimates in outcrops (see Pedrazzi Pedrazzi et al. 2014c et al. 2014 for more stratigraphic details).

Variations in thickness and distribution are consistent with a north-eastward pattern of isopachs (Baker et al. 1975) and median grain size diameter ( $\mathrm{Md} \varphi$ ) isoline maps ( Pedrazzi Pedrazzi et al. 2014c et al. 2014) both extending along the axis of the South Shetland Islands (Fig. 4b, c). Applying the method of Bonadonna and Costa (2013) based on the Weibull distribution between volume and square root of isopach area from the map of Baker et al. (1975), we estimate a minimum bulk eruptive volume of $0.1 \mathrm{~km}^{3}$ for the 1970 event.

\section{Subglacial 1969 eruption}

Here, we collate a brief description of the 1969 eruption (Fig. 5) based on the initial report of Baker et al. (1975) and the more detailed synthesis of Smellie (2002). The 1969 eruption represents an important event among the historical eruptions at DI, due to the involvement of magma-ice interaction and subordinate hydrovolcanic activity.

Similar to the 1967 and 1970 events, earthquakes and tremors preceded the beginning of this eruption. The 1969 eruption, which lasted 2 days (21 to 22 February 1969; Baker et al. 1975), occurred along a series of echelon fissures that were situated beneath the Mount Pond glacier (see map of Smellie 2002 as given here in Fig. 5). This eruption was associated with a widespread flood of meltwater jökulhlaup (Fig. 6o) that flowed toward the Pendulum Cove and Port Foster Bay, leading to the extension of the local coastline. These events severely damaged the British scientific station, leading to its abandonment. The Chilean station (already affected by the 1967 eruption) was also destroyed (Baker et al. 1975; Smellie 2002).

According to the description of Smellie (2002), the eruptions through the Mount Pond glacier produced two main morphological features. The most prominent were three gaping ice fissures. These were 500-1000 m in length, 100-150 m wide, and 70-100 m deep, with almost vertical ice walls (Table 1). Two groups of three overlapping pyroclastic cones were constructed in fissures $\mathrm{C}$ and $\mathrm{E}$ (Fig. 5c, d) and glowing lava was observed beneath the pyroclasts in both groups of cones. There was no evidence of eruptive activity in fissure F. Four circular-to-ovoid ice chimneys (using the terminology of Gudmundsson et al. 1997) were also present (features A, B, D, and G, Fig. 5c, d) and a small chimney also occurred on the floor of fissure F (nomenclature A-F from Smellie 2002).

Baker et al. (1975), based on their isopach map, estimated that $0.02 \mathrm{~km}^{3}$ of bulk volume of tephra (excluding near-vent deposits) was ejected during the 1969 eruption (Table 1). The dominant pyroclasts were dark grey vesicular lapilli, with a 
smaller proportion of red vesicular lapilli and scarce fragments of yellow lapilli tuff (OCTF). Maps of the tephra distribution, thickness variations, and maximum clast size show a strong N-S geometry indicating control by a northerly wind (Fig. 5a, b). However, a thin layer of black ash was deposited during the final stages of the eruption and was distributed more to the SW, marking a late change to north-easterly winds (Baker et al. 1975).

Baker et al. (1975) estimated that $0.01 \mathrm{~km}^{3}$ of magma volume was preserved in the near-vent deposits. The tephra accumulated on the glacier surface, to at least 20-50 m in thickness, down-slope of fissures C and E (Smellie et al. 2002). Bombs 1-2 $\mathrm{m}$ across are also scattered over the surface; they increase in size and abundance upslope. Baker et al. (1975) also described blocks of dense brownish lava around cones in fissure E. Unstratified bomb and scoria deposits characterise the topographically highest exposures, on the east side of the inner wall of the northernmost crater; similar massive deposits were exposed nearby to the south and were probably formed on the inner crater slopes of the central (largest) cone.

Topographically, the lowest exposures comprise scoria (grey in the upper $0.5-1 \mathrm{~m}$, and bright red at the bottom). Those deposits are mainly formed by bombs of up to $40 \mathrm{~cm}$ across and finely vesicular coarse scoria $(4-5 \mathrm{~cm}$, ranging up to $15 \mathrm{~cm}$ ) with lenses of red fine lapilli $1-2 \mathrm{~cm}$ in length and 5-15 cm thick. Upper parts of the deposit contain large ribbon bombs (up to $2 \mathrm{~m}$ ) dispersed in equant to oblate vesicular lapilli. Nowadays, the 1969 craters are buried under the ice and snow of Mount Pond.

\section{Petrology and geochemistry}

In hand sample, scoria samples that erupted during the historical eruptions of DI are characterised by a fine-grained glassy groundmass sharing space with both dark scoriaceous material that yield to a typical aspect of vitric tuff and local lithic fragments of mafic volcanic rocks. In thin section, the aphanitic groundmass shows a small-volume of embedded crystals (up to $10 \%$ of the total rock). These crystals are mainly comprised of microlites (needle-shaped laths) of plagioclase and euhedral pyroxene (both clino and ortho), local small phenocrysts $(<<1 \mathrm{~mm}$ ) of olivine (Fig. 7a, b) and pyroxene, and minor larger phenocrysts of euhedral to subeuhedral plagioclase (locally displaying twining and zonation, Fig. 7c), mainly in basalts and basaltic andesites. Occasionally, microlites are aligned in a flow texture that wraps around the phenocrysts, yet they typically show random distribution within the glassy matrix. Bubble volumes and shapes (in places, infilled by fibrous zeolite) vary as a function of their host glass, which in turn varies from totally fresh/unaltered to devitrified/altered, i.e. from basaltic sideromelane (quenched glass, clear, and isotropic) transforming to palagonitic (yellowish-orange) (Fig. 7d). Some microtextures show relict shapes of sideromelane shards altered to palagonite. Normally, the smaller sideromelane areas, recognised in hand sample and microscopic study, show a higher degree of palagonitisation than the wider sideromelane areas (Stroncik and Schmincke 2002).

\section{Fig. 7}

Microscopic general views of the post-caldera Crimson Hill and Kroner Lake eruptions. Details of the palagonitic glassy and vesicular matrix with plagioclase microlites and olivine phenocrysts $\mathbf{a}$ in plane-polarised light and $\mathbf{b}$ with crossed polars. $\mathbf{c}$ Detail of (in plane-polarised light) a plagioclase phenocryst within a palagonitic groundmass and $\mathbf{d}$ sideromelane + palagonitic glassy matrix including glass shards 


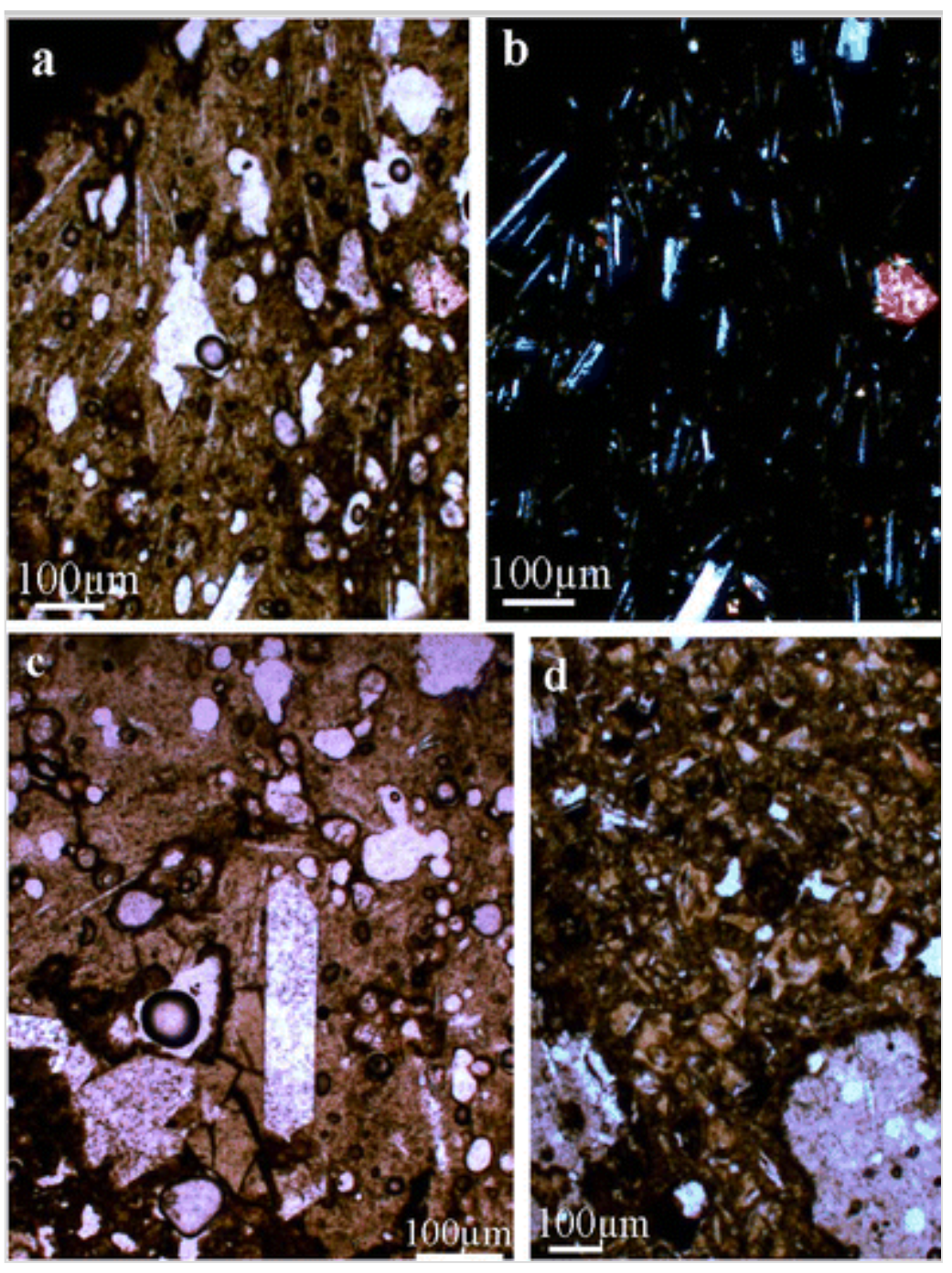

From a geochemical perspective, and compared to the rest of the quaternary volcanoes within the Bransfield Strait, DI is compositionally special as major element contents provide evidence for a differentiation trend (alkali enrichment as a function of silica) from mafic to intermediate compositions; i.e. DI contains a wide range of magmas extending from basalts to dacites (e.g. Keller et al. 1992). Focussing on a total alkali-silica (TAS) diagram, samples from historical eruptions of this study are grouped within the alkaline and subalkaline fields (Fig. 8), matching a wide range of rock series (mainly basalts, trachybasalts, basaltic trachyandesites and trachyandesites) according to the classification of Le Bas et al. (1986). Within this trend, there is an additional systematic grouping, i.e. samples from the 1967 and 1970 eruptions and from Kroner Lake are higher in silica and alkalis than products from the 1969 eruption and Crimson Hill (Fig. 8, Supp Mat 3 ). This systematic grouping corroborates with the compositional behaviour of the $\mathrm{CaO}, \mathrm{FeO}, \mathrm{MgO}$, and $\mathrm{TiO}_{2}$ contents, and $\mathrm{K}_{2} \mathrm{O}, \mathrm{Na}_{2} \mathrm{O}$, and $\mathrm{P}_{2} \mathrm{O}_{5}$ contents, decreasing and increasing, respectively, as a function of silica enrichment (Fig. 9). In contrast, $\mathrm{MnO}$ content remains constant, and $\mathrm{Al}_{2} \mathrm{O}_{3}$ shows a clear trend with constant silica only for the 1969 eruption material. Trace elements and REE display the same mentioned systematic grouping according to the different eruptive events and locations (Fig. 10). Minor elements (Rb, Ba, Zr, Y, Nb, Zn, Y, Nb, Th, Hf, Ta, U, Pb, Cs) and REE show linear enrichment trends versus silica content. In contrast, elements $\mathrm{Sr}, \mathrm{Sc}$, and $\mathrm{Cu}$ display an opposite trend of depletion toward richer $\mathrm{SiO}_{2}$ samples (Fig. 10).

Fig. 8

TAS diagram for the samples of the 1967, 1969, 1970, Crimson Hill, and Kroner Lake eruptive events. Grey dashed line discriminates between the alkaline-subalkaline fields (Irvine and Baragar 1971). Selected representative rock samples of this study (Supp Mat 3) are combined with geochemical data from previous studies (see legend) 


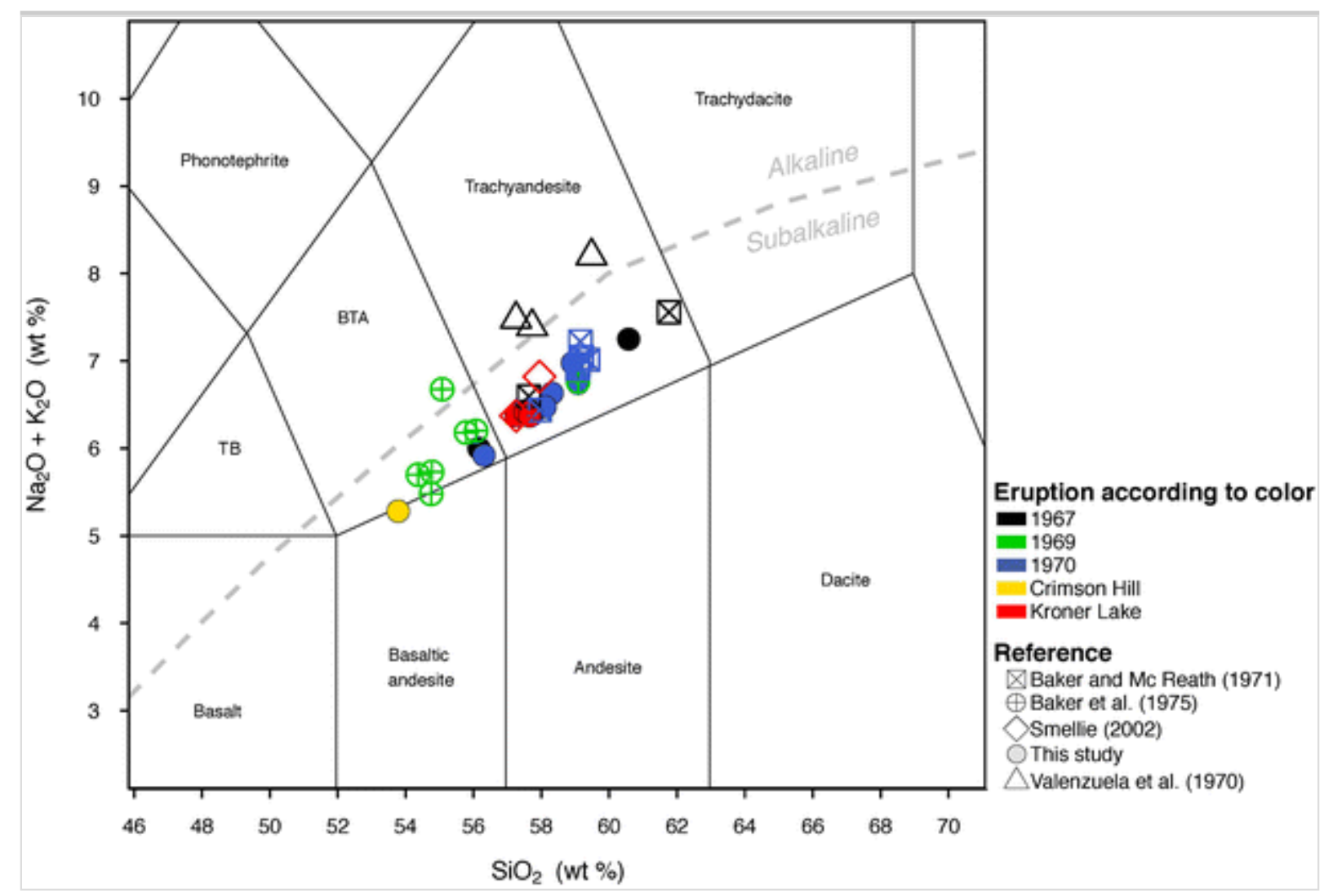

Fig. 9

Harker diagrams of major elements (in wt\%) for the samples of the 1967, 1969, 1970, Crimson Hill, and Kroner Lake eruptive events. Legend as per Fig. 8
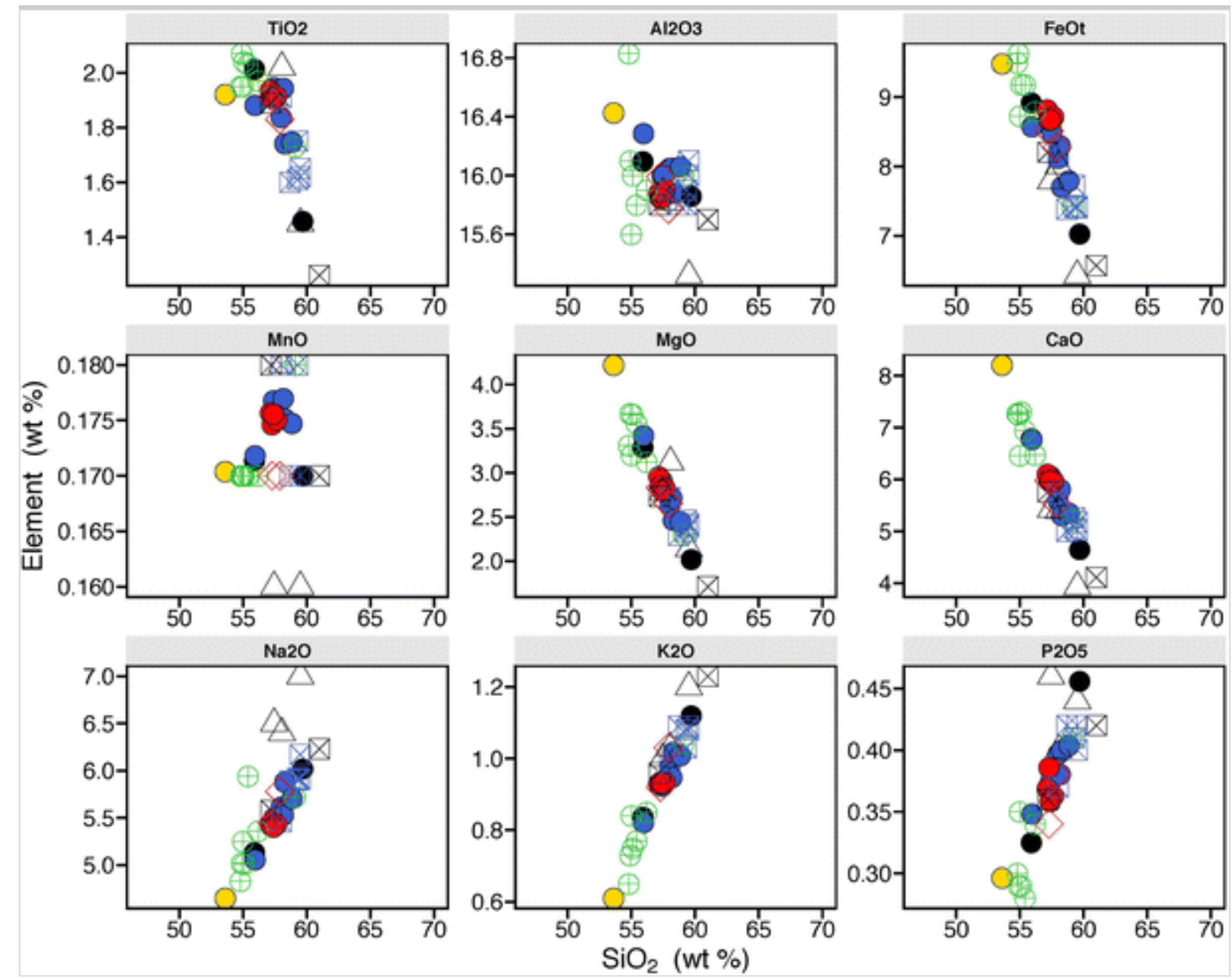

Fig. 10

Harker diagrams of trace and rare elements (in ppm) for the samples of the 1967, 1969, 1970, Crimson Hill, and Kroner Lake eruptive events. Legend as per Fig. 8 


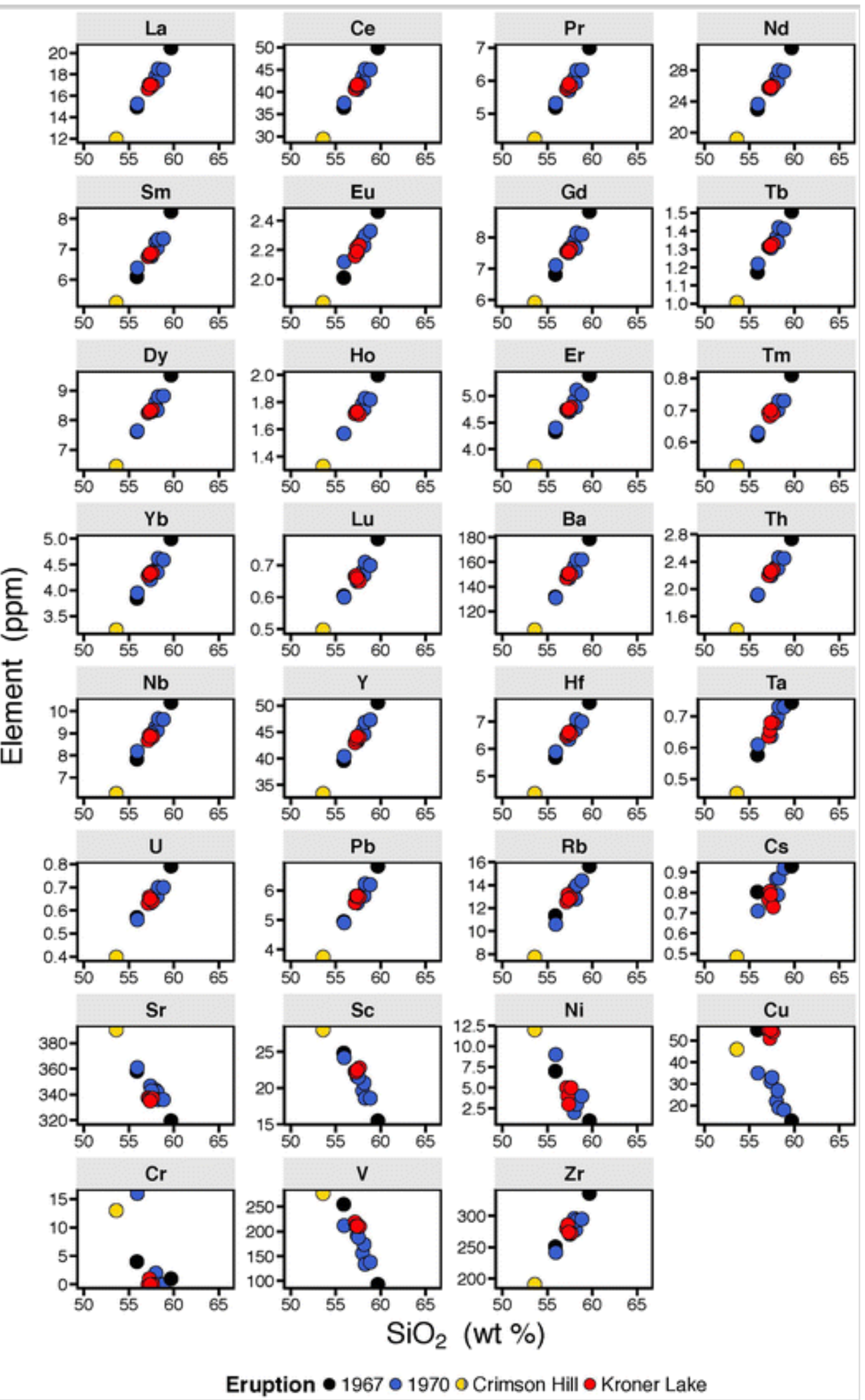

Deuterium $(\delta \mathrm{D})$ and oxygen $\left(\delta^{18} \mathrm{O}\right)$ stable isotopes in volcanic products provided essential information about the potential influence (isotopic equilibria) of non-magmatic fluids on the primary fluids' magma composition. This results in two representative post-caldera products (DI-64; DI-61 that correspond to Kroner Lake and Crimson Hill; Fig. 2) that range from -37.5 to $-31.1 \%$ for deuterium, respectively, and $6.0 \%$ for oxygen (Fig. 11), and indicates (i) a negligible $\delta^{18} \mathrm{O}$ fractionation that is typical for such high T magmas (see also Bindeman 2008), as well as (ii) an increasing influence of non-magmatic waters (oceanic, ice) as revealed by the shift toward heavier-SMOW—deuterium values.

Fig. 11

Diagram of $\delta$ D vs. $\delta^{18} \mathrm{O}$ results (\%o) measured in two DI post-caldera samples (modified from Taylor 1967). Note that the high temperature of the basaltic DI magmas did not allow for oxygen equilibration or fractionation in these rapid eruptions. The $\delta \mathrm{D}$ values differentiate the water provenances of the two samples 


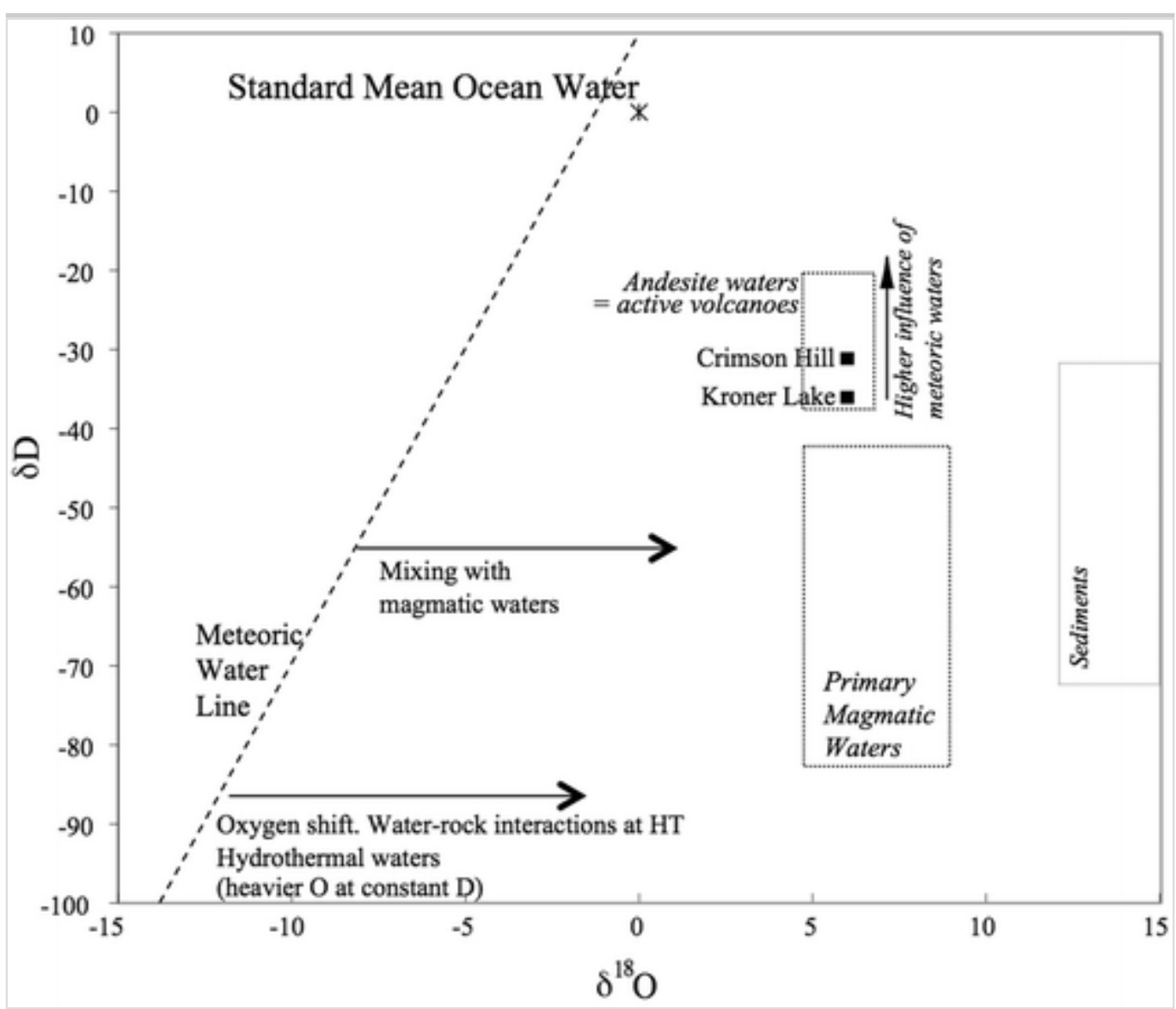

\section{Discussion}

We have demonstrated that magma-water interaction is one of the most relevant factors controlling recent post-caldera volcanic activity at DI. Field characteristics such as impact bomb sags underneath blocks and bombs, explosion breccia of fall origin, and dilute deposits of PDCs (pyroclastic density currents) origin (Fig. 6) represent a first line of evidence. The deposits described here are similar to those from pre-historic and historic hydrovolcanic eruptions: such as the 4000 BP Songaksan tuff ring eruption of Jeju Island, Korea (Sohn et al. 2003); the 500 years BP phreatomagmatic phase of Rangitoto Volcano, Auckland, New Zealand (Needham et al. 2011; Kereszturi et al. 2013); the 1245 years BP Asososca maar eruption in Nicaragua (Pardo et al. 2009); the 1913 maar-forming eruption in West Ambrym, Vanuatu (Németh 2011); the 1949 eruption on La Palma in the Canary Islands (White and Schmincke 1999); and the 1977 eruption of Ukinrek maars (Self et al. 1980). In addition, the presence of, fragments of country-rock (Fig. 6b, c, j, n), low vesicularity of juveniles products (Fig. 6e) and palagonitisation of matrix glass (Fig. 7) is unambiguous evidence in support of hydrovolcanic activity. Interpretation of magma-water interaction and emplacement dynamics is provided mainly through proximal deposits, because of the lack of distal ones (except for 1967 eruption), as a consequence of erosion or owing to the difficult access to some areas (mainly because of weather conditions and ice cover).

Variable degrees of explosivity and corresponding eruption dynamics have been inferred here, depending on the water abundance and mobility. That is, for Port Foster Bay's case, water came from the underground aquifer, meltwater, and glaciers and this interacted with the rising or erupting magma. Explosivity and eruption dynamics also depended on the explosion loci of the eruptions. In some cases, as for Crimson Hill, the finer grain size of the deposits recorded by the presence of abundant fine ashfall and thin PDC deposits might indicate energetic explosive fragmentation due to hydrovolcanic activity with an optimal magma-water energy transfer and/or optimal-to-deeper subsurface explosion loci of the eruptions (Valentine et al. 2015a, b; Macorps et al. 2016). In contrast, unsorted, massive volcanic breccias (as with most of deposits of the 1967 eruption; Crater 70 or Kroner Lake) are inferred to be more consistent with explosive eruptions controlled either by high water/magma ratio (Sheridan and Wohletz 1983; Wohletz and McQueen 1984; Wohletz et al. 2013 ) and/or explosion depths that were very shallow so that the explosions lost kinetic energy quickly to the free surface preventing effective fragmentation and excavation (Valentine et al. 2014; Valentine et al. 2015a, b; Macorps et al. 2016; Graettinger et al. 2015a, b).

AQ14

The Crimson Hill and Kroner Lake eruptions occurred close to the current coastal margins where shallow seawater or groundwater is present (Fig. 2). This case is similar to the Holocene Marion and Prince Edward Islands eruptions (Verwoerd and Chevallier 1987); the $<500$ and < 300 years B.P. Ambae Island eruptions, Vanuatu (Németh and Cronin 2009); the Quaternary Hanauma Bay, O'ahu, Hawai'i (Rottas and Houghton 2012); and the October 1983 eruption of Miyakejima Volcano (Aramaki et al. 1986).

The sequence observed at Crimson Hill characterised mainly by thinly bedded or laminated layers with subordinate medium poorly vesicular clast-supported beds that have crude layering in a matrix of fine lapilli and coarse ash with ballistic ejecta (Fig. 6b, c). Similar deposits forming emergent tuff cones over a shallow sea adjacent to coastal plains were also observed at Dangsanbong tuff cone, Jeju Island, Korea (Sohn and Park 2005); Montaña Pelada Tuff Ring: Tenerife, Canary Islands 
(Carmona et al. 2011); Capelas Tuff Cone, Sao Miguel-Azores Islands (Solgevik et al. 2007); and El Golfo tuff cone, at Lanzarote-Canary Islands (Pedrazzi et al. 2013).

This eruption is the consequence of hydrovolcanic activity without any evidence of pure magmatic phases through the whole sequence. Interaction of water with magma, mostly at sea level, dominated the first stages of the eruptive process (Fig. 12aI). Following Sottili et al. (2009), Graettinger et al. (2014), and Valentine (2015), the presence of lithics from the BSF and the OCTF is also indicative of interaction with the underlying substrate (Fig. 12aII). The hydrovolcanic blasts could have disrupted a possibly fractured aquifer in the BSF, enhancing secondary permeability, thus increasing the hydraulic conductivity. At Crimson Hill, magma-water interaction is also supported by the presence of extensive postdepositional palagonitisation of the pyroclastic successions, indicative of steam retention shortly after pyroclastic material deposition. This process might be similar to those observed at Montaña Amarilla and Montaña Los Erales (Tenerife, Canary Islands) (De la Nuez et al. 1993; Clarke et al. 2009), El Golfo Tuff Cone (Canary Islands) (Pedrazzi et al. 2013), and Capelinhos and São Roque Tuff Cones (Azores) (Cole et al. 2001; Zanon et al. 2009).

\section{Fig. 12}

Sketch (not to scale) illustrating the evolution of a Crimson Hill, b Kroner Lake, c 1967, d 1970, and e 1969 eruptions. (aI) rise of magma and interaction with post-caldera deposits and (aII) subsequent growth of Crimson Hill crater; (bI) rise of magma and interaction with post-caldera deposits and (bII) subsequent growth of Kroner Lake craters in shallow seawater; (cI) rise of the magma and (cII) interaction with the post-caldera syn-caldera and pre-caldera deposits; (ci) interaction of the ascending magma with shallow marine water and (cii) interaction with the basement made of syn-caldera deposits. Similar pattern of $\mathbf{c}$ is also observed for 1970 eruption in (dI-dII) and (di-dii); (eI) pressurised hot gases lifting the glacier with subglacial melting above each vent; (eII) subglacial space beneath the lofted glacier is filled with meltwater, which overflows. At the same time, hydrovolcanic activity occurred during this early phase; (eIII) activity ceased at the ice chimney, but continued to construct a supraglacial cinder cone at the fissure. Only minor meltwater is now present, draining subglacially, and eruptions are essentially dry (Hawaiian-Strombolian) (data from Irvine 1971; Smellie 2002) 

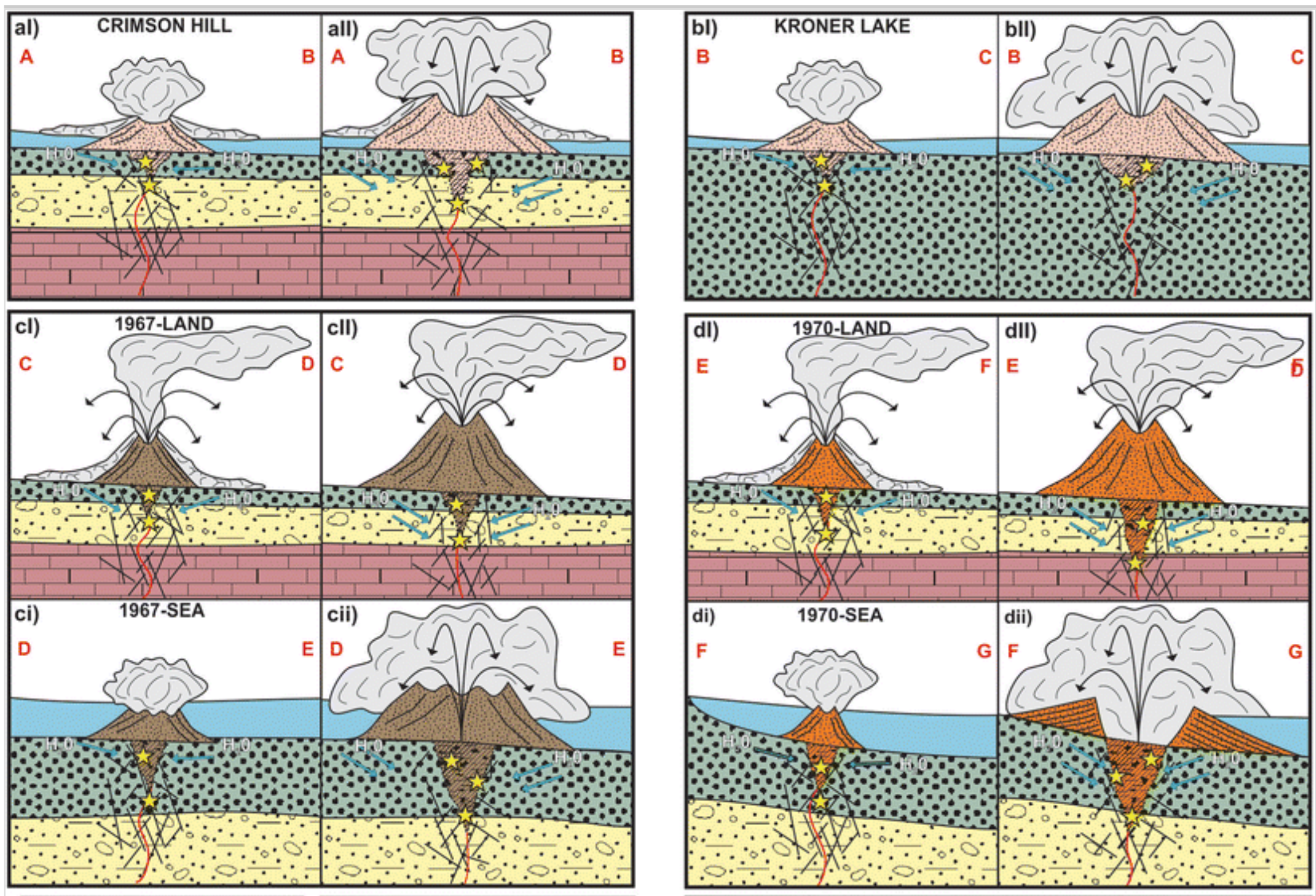

\begin{tabular}{|c|c|}
\hline LEG & END \\
\hline & Sea \\
\hline 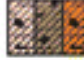 & Breccia deposits \\
\hline 8 & Volcanic deposits \\
\hline$\because$ & Post-caldera deposits \\
\hline & Syn-caldera deposits \\
\hline & Pre-caldera deposits \\
\hline & Volcanic deposits \\
\hline & Meltwater \\
\hline & Glacier \\
\hline & Bedrocks \\
\hline exe & $\begin{array}{l}\text { Phreatomagmatic } \\
\text { activity }\end{array}$ \\
\hline 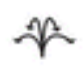 & Ballistic fallout \\
\hline$b$ & PDCs \\
\hline$x|x| x$ & Fracture zone \\
\hline 7 & Infiltration area \\
\hline 次 & Explosion locus \\
\hline j & Dyke \\
\hline
\end{tabular}
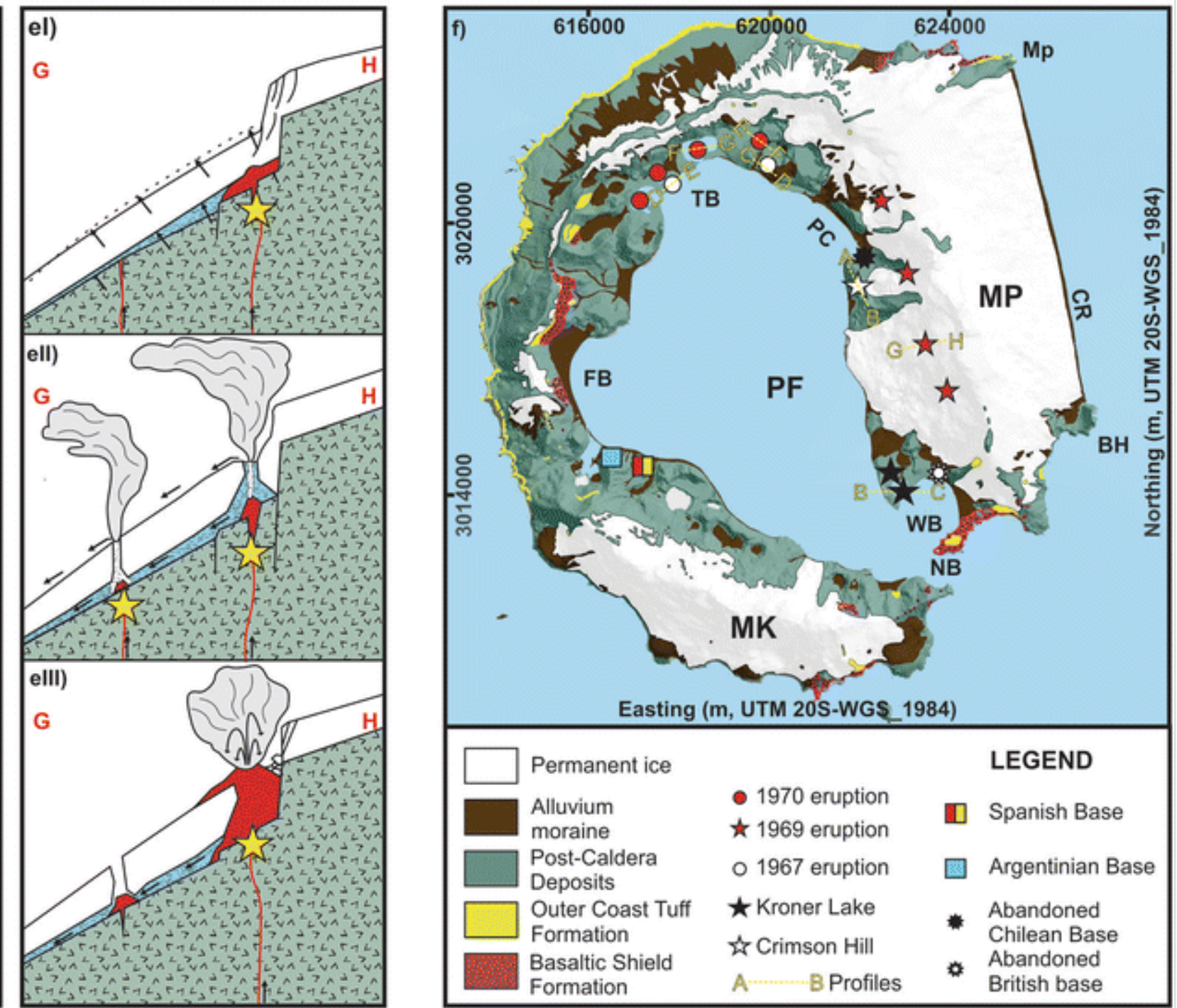

AQ15

The Kroner Lake sequence (Fig. 2) is mostly characterised by massive deposits of poorly vesicular juvenile scoriae lapilli that are indicative of fallout deposits with subordinate laminated beds of poorly vesicular scoria lapilli, which suggest emplacement by dilute PDCs (Figs. 2 and 6e). Field evidence and the abundance of low vesicularity of scoriaeceous pyroclasts also supports magma-water interaction, although a few beds show highly vesicular juvenile scoriae bombs and lapilli (Fig. 6f). These small shifts to relatively dryer conditions might be related to changes of vent geometry; cone growth in general act to restrict the ingress of water but a collapse of the inner walls of the growing cone may promote renewed magma-water interaction by the addition of water-saturated tephra to the eruption site. A shift from hydrovolcanic to volcanic eruption style within individual volcanoes and across a volcanic field is a common feature of monogenetic volcanism in low-land regions in humid climate as observed in the Catalan Volcanic Zone (Spain) (Martí et al. 2011) or in the Auckland Volcanic Field (New Zealand) (Kereszturi et al. 2014).

The Kroner lake eruption occurred close to Whalers Bay (Fig. 2), suggesting interaction with shallow seawater very close to the coastline. In contrast with the Crimson Hill eruption, no lithic clasts were observed in the deposits of Kroner Lake, 
suggesting that the eruption may only have occurred very close to the surface (Fig. 12bI-II), with fragmentation driven by the combination of magmatic volatiles expansion and magma-water interaction.

The 1967 (Fig. 3) and 1970 (Fig. 4) eruptions are very similar in that (i) both occurred between Goddard Hill and Cross Hill, at the north-western coast of Port Foster Bay (Figs. 1, 3, and 4); (ii) during both eruptions, several clustered vents opened during at the same time in different parts of the island to generate diverse types of craters and cones with contrasting eruptive styles; (iii) while onshore events, close to the coastline (Fig. 12cI-cII, dI-dII), and due to contact with water-saturated or icy substrates, offshore events were due to the interaction with seawater (Fig. 12ci-cii, di-dii). Field data from the 1967 and 1970 eruptions suggests alternating volcanic and hydrovolcanic phases (Figs. 3 and 4) with fallout, ballistic blocks and bombs, and subordinate dilute PDC currents (Fig. 61, n) with no lava flows (see also Baker et al. 1975 and Pedrazzi Pedrazzi et al. 2014c et al. 2014).

As already proposed in Pedrazzi et al. (2014) Pedrazzi et al. 2014c .... the "land" centres of 1967 and 1970 eruptions were the result of interaction between magma and a possibly fractured aquifer inside the OCTF and BSF, with a possible initial first subglacial phase (Fig. 12cI-cII, dI-dII). Conversely, "island" centres started with a submarine eruption assumed by comparing the current position of the coastline with that of 1967 and 1969) in shallow water, later evolving into a subaerial phase (Fig. 12ci-cii, di-dii). Magma-water interaction is also supported by deposit characteristics (lithic-rich deposits and poorly vesicular, chilled juvenile pyroclasts) of both eruptions (Fig. 6).

AQ17

Concerning the 1969 eruption, there is no evidence for significant involvement of external water during the eruption as proposed by Smellie (2002). During the first eruptive stage (Fig. 12eI), pressurised hot gases lifted the glacier, with subglacial melting occurring above each vent. The subglacial space beneath the lofted glacier was filled subsequently with meltwater, which eventually overflowed (Fig. 12eII). Hydrovolcanic activity was coeval with this early stage. During the last stage (Fig. 12eIII), eruptive activity ceased at the ice chimney, but continued to construct a supraglacial cinder cone at the fissure with only minor meltwater, draining subglacially, and the eruption becoming essentially dry (i.e. HawaiianStrombolian). An important feature of the eruption was, thus, the rapid generation of abundant meltwater-from melting of the glacier above the fissures. The meltwater overflowed onto the glacier surface and generated a flood (Fig. 6o) that modified the glacier, extended the local coastline, and destroyed buildings in its path.

Eruption dynamics, which were partly related to the efficiency of hydrovolcanic fragmentation, depend on the precise nature of the coolant (White 1996), the pressure differences between magma and water and the water-magma contact mode (Wohletz and Sheridan 1983). Eruptive styles are also controlled by the magma flux rates and the magma's physicochemical properties (Houghton et al. 1999; Parfitt 2004). Although some chemical variation among magmas are observed during the historical volcanism at DI here (Fig. 8 and Supp Mat 3), on the basis of deposit characteristics, we inferred that the availability of water or other external fluids acted as first order agents to influence the style of hydrovolcanism that is responsible for the formation of the small-volume volcanoes of Crimson Hill (less than $0.1 \mathrm{~km}^{3}$ ), Kroner Lake $\left(0.005 \mathrm{~km}^{3}\right), 1967\left(0.05 \mathrm{~km}^{3}\right)$, and $1970\left(0.1 \mathrm{~km}^{3}\right)$. Such bulk volumes are well beyond the common eruptive volumes associated with typical monogenetic eruptions (Németh and Kereszturi 2015). This matches the different stable isotope results, progressively heavier from Kroner Lake to Crimson Hill (Fig. 11), which suggest a higher influence of meteoric waters during the respective eruptive processes. We are aware that a post-hydration event might have occurred, or at least had affected the isotopic ratios. However, given that the water amount within the rock is relatively so small, any water-rock interaction immediately affects the deuterium/hydrogen $(\mathrm{D} / \mathrm{H})$ isotopic ratio, shifting to heavy values in the rock. Therefore, any influence of non-magmatic water (after the eruption event), which must be common for all samples in the island, would have immediately homogenised their hydrogen isotopic signal.

AQ18

One of the main issues concerning hydrovolcanism is that, although small magma volumes might feed the eruption of a single monogenetic centre, the host environment exerts a strong influence on the style of eruption (e.g. Lorenz 2003; Ross et al. 2011; Valentine et al. 2014; Graettinger et al. 2014; Graettinger et al. 2015a, b). DI is a particularly good example, demonstrating how a single eruption may promote a complex sequence of eruption styles and depositional processes. AQ19

Due to the potential for hydrovolcanic activity on the island, even small-volume eruptions can be highly explosive in the case of shallow submarine vents or those located on waterlogged shorelines or beneath the ice caps (Baker et al. 1975; Smellie 2002; Pedrazzi 2014c et al. 2014). Indeed, the presence of glass shards (after quench fragmentation) within a hydrovolcanic environment, such as that described for DI (Fig. 7d), indicates violent explosions during the eruption. Therefore, the location of the eruptive vent (in shallow seawater and at onshore ice-free locations) strongly controls the potential magma-water interaction and the possible hazards to be expected during any future eruption on DI. A similar correlation has been recently recognised between the external parameters (near-surface hydrologic, topographic, and 
geologic data) and the location of new vents from Auckland Volcanic Field, using a logistic regression method for mapping phreatomagmatic-magmatic eruption transition susceptibility (Kereszturi et al. 2014, 2017; Smith and Németh 2017).

A fissure-dominated system may exhibit Hawaiian-Strombolian style eruptions with hydrovolcanic activity, as for the case of the 1970 eruption land centres. However, shallow submarine conditions allowed the development of different types of hydrovolcanic landforms in areas such as Crimson Hill, Kroner Lake, and the 1967 and 1970 island centres.

Direct observations of past eruptions, together with the results obtained in this study in terms of stratigraphy, as well as the lithology and depositional features combined with those collected by other authors during previous field campaigns (e.g. Orheim 1971; Roobol 1973, 1980, 1982; Baker and McReath 1971, Baker et al. 1975; González-Ferrán et al. 1971; Shultz 1972; Smellie 2002, Smellie et al. 2002; Pedrazzi 2014c et al. 2014), indicate that hydrovolcanic activity from maars and tuff cones is the cause of major and direct volcanic hazards at DI. These include ashfall and ballistics, and subordinate dilute PDCs that are probably the least predictable and the most dangerous of all volcanic hazards. In addition, tsunamis triggered by eruptions and slope failures might be related to this type volcanic activity on DI (Smellie 2002).

A small lava spatter eruption may be manageable on DI, but the emplacement of a tuff cone or maar-like eruption would cause destruction on a local scale impacting people and military bases) and would therefore have very different repercussions in terms of its potential hazards. A major concern in DI is related to ash emission since deposits, such as those of the 1967 and 1970 eruptions (Figs. 3 and 4, Baker et al. 1975), could easily cover the whole island, which has an approximate diameter of $13 \mathrm{~km}$ (Fig. 1). Due to the strong winds and the unusually low tropopause (8-10 km) in the area (Geerts and Linacre 1997), ashfall deposits, as observed for the 1970 eruption, can be dispersed rapidly over neighbouring islands (Baker et al. 1975; Smellie 1999; Pedrazzi 2014c et al. 2014) and the Bransfield Strait (Fretzdorff and Smellie 2003) (Fig. 4b,c). This would be similar to the Eyjafjallajokull eruption (between 15 April and 23 May 2010), where fine ash (radii $<63 \mathrm{~mm}$ ) were dispersed into the mid troposphere $(3-8 \mathrm{~km})$, which due to the prevailing westerly and northwesterly winds during the period reached continental Europe (Prata and Rose 2015).

Close to the vent, ash fallout could lead to severe building damage as observed at the abandoned Chilean station in Pendulum Cove (Fig. 13a) that was totally destroyed by the 1967 eruption. In addition, as observed for 1967 and 1970 eruptions (Fig. 6j, n), bombs and blocks might have a direct impact on people and infrastructures, depending on the projectile's impact energy and on distance_-as reported during the recent 2014 Ontake, Japan (Maeno et al. 2016) and the 2012 Te Maari, New Zealand (Pardo et al. 2014; Breard et al. 2015) eruptions and as observed around large-scale analogue experiments (Graettinger et al. 2015a, b). Short-term respiratory effects related to volcanic ash, including asthma and bronchitis (Horwell and Baxter 2006; Gudmundsson 2011) could affect tourists (Fig. 13b) in addition to scientists and military staff (Fig. 13c, d) living on the islands.

\section{Fig. 13}

a Remains of the Chilean base after 1967 and 1969 eruptions; damage is due to fallout and jökulhlaup and b a tourist cruise at Pendulum Cove (inside Port Foster main hazards would be related to fallout and dilute PDCs). c Spanish Base Gabriel de Castilla and d Argentinian Base Decepción. Both bases, in the case of hydrovolcanic eruptions, would be affected; as would be as already occured to the Chilean and Norwegian bases. Remains of e British Base and f Norwegian whaling station at Whalers Bay due to jökulhlaup as consequence of the 1969 eruption. (See Fig. 1b for exact locations) 

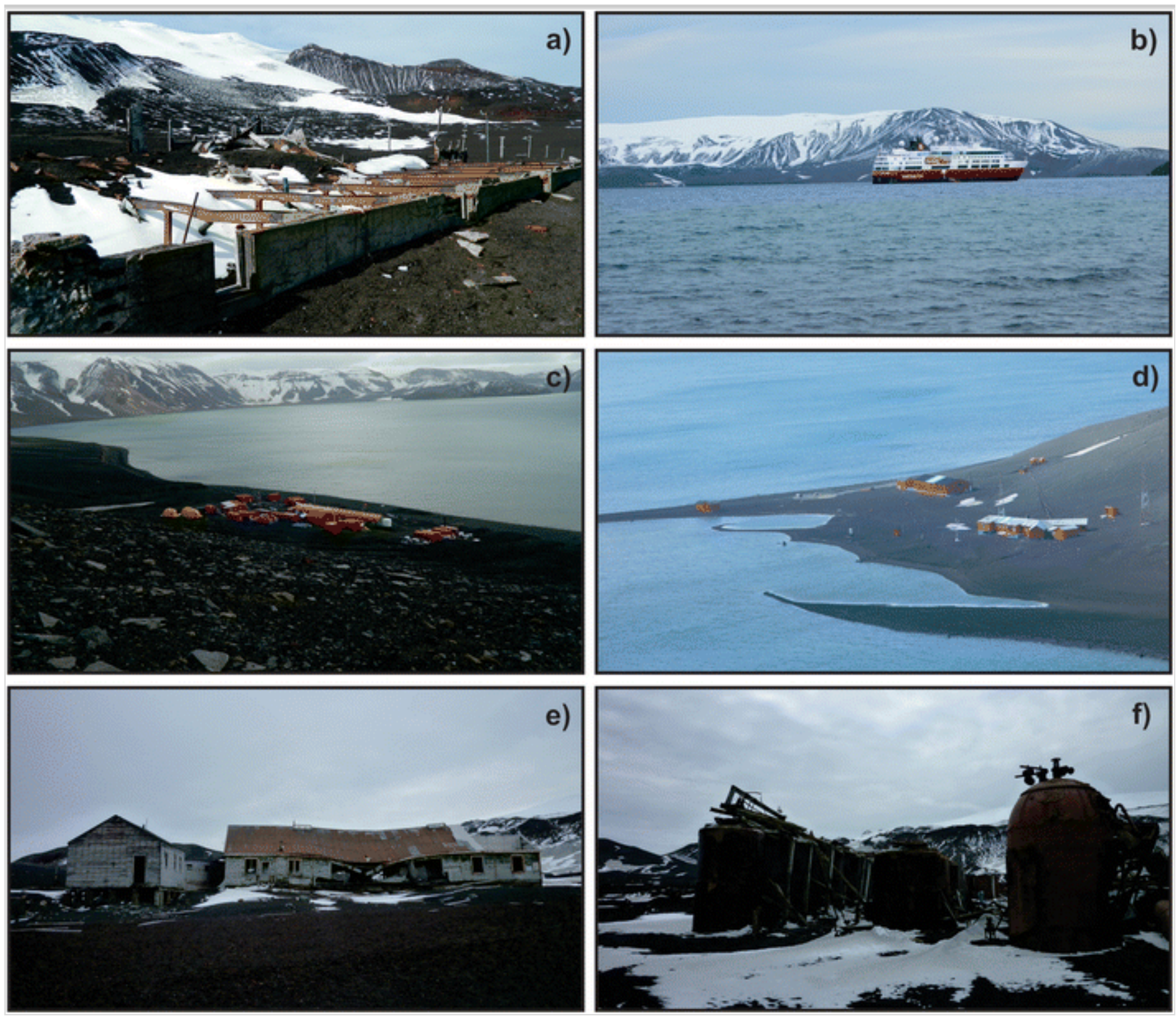

Dilute PDCs represent a second major issue at DI as observed for the Crimson Hill eruption. Damage to infrastructure on DI would depend on the dynamic pressure, temperature, duration of flows, and the amount of solid material carried by the flow, with degree of damage increasing with each variable. Recent directed blasts, similar to those observed on DI, occurred at Mt. Pelée, Martinique in 1902, Lamington, Papua New Guinea, in 1908 and 1951; Bezymianny, Kamchatka in 1956; Soufrière Hills, Montserrat in 1997; and Merapi, Indonesia in 2010 (Cole et al. 2015).

The recent eruptions on DI (such as the 1969 event, Baker et al. 1975; Smellie et al. 2002) have also demonstrated that jökulhlaups (Gudmundsson et al. 1997) are also a major hazard on the island since because great bulk density and velocity make them highly destructive. Jökulhlaups produced by the 1969 eruption were responsible for the destruction of the British scientific station (Fig. 13e) and infrastructure related to the whaling industry (Fig. 13f) at Whalers Bay (Baker et al. 1975). Jökulhlaups with similar dynamics and deposits were also observed in Iceland in the Vatnajökull area (Gudmundsson et al. 1997; Björnsson 2003) and at Kverkfjöll volcano (Carrivick et al. 2004; Carrivick 2007).

It is therefore necessary to focus on the expected volcanic hazards as a consequence of magma-water interaction. A first attempt to construct a volcanic hazard map of Deception Island was made by Roobol (1982), who mainly focussed on assessing the zones threatened by lahars using topographic data and the extent of the ice cap. Later, Smellie (2002) used observations of the extent of the products of the historical eruptions of 1842, 1967, 1969, and 1970 to produce a map that included possible areas affected by tsunamis and areas with low, mildly, and highly explosive eruptions due to ashfall, surges, and lava flows. Recently, Bartolini et al. (2014) provided a volcanic hazard map that estimated the probability that the different areas may be invaded by lava flows, lahars, and/or PDCs. In all three cases, hazard assessment on DI has always been limited by the lack of a complete geological record and by full knowledge of the dynamics of post-caldera eruptions.

It is clear at DI that the spatial distribution of different eruption styles and eruptive histories are related to the landscape, tectonic setting, and hydrology. Based on the results obtained in this paper, we have tentatively mapped inside the DI caldera - according to the historical volcanism and following the structural limits proposed by Martí et al. (2013) — the possible type of hydrovolcanic activity to be expected during a future volcanic eruption at DI to depend on the outcoming vent location. This qualitative map divided DI into five areas (A-E) depending on the potential type and style of hydrovolcanic activity to be expected during a future eruption, as based on observed historical eruptions and our analyses (Fig. 14):

A. Deepest water depths at Port Foster Bay (> $150 \mathrm{~m}$ b.s.1.), means that mainly submarine activity, with a possible evolution to Surtseyan activity due to an increasing volume of the volcanic edifice and a decrease of the water cover, will be likely here. 
B. Intermediate water depths at Port Foster Bay (150-100 m b.s.1.), means that submarine activity with the possibility of Crimson Hill, Kroner Lake, and 1967, 1970 “island”-like hydrovolcanic eruption, will be likely here.

C. The shallow depths of Port Foster Bay (100 m b.s.1.- $0 \mathrm{~m}$ ) favour magma-seawater interaction with the possibility of Crimson Hill, Kroner Lake, and 1967, 1970 “island”-like hydrovolcanic eruptions.

D. At the actual coastline (Port Foster Bay and the outer coast) and inner areas, there is the possibility of magma-aquifer interaction and a 1967 or 1970 "land"-like eruption.

E. On land, there is the potential for magma-ice interaction with a 1979-like eruption.

Fig. 14

Map showing the type of volcanic activity depending on susceptibility inside the caldera at DI. A, submarine activity corresponding to the deepest part of the bay $(>150 \mathrm{~m})$; B, intermediate depth (150-100 m b.s.l.) submarine activity with the possibility of Crimson Hill, Kroner Lake, and 1967, 1970 "island"-like eruptions; C, shallow depth (100-0 m b.s.1.) submarine activity with the possibility, Crimson Hill, Kroner Lake, and 1967, 1970 "island"-like eruptions; D, land, magma-aquifer interaction activity, with 1967 and 1970 "land"-like eruption; E, land activity with magma-ice interaction, leading to a 1969like eruption. Abbreviations in Fig. 14 refer to toponyms of Fig. 1c

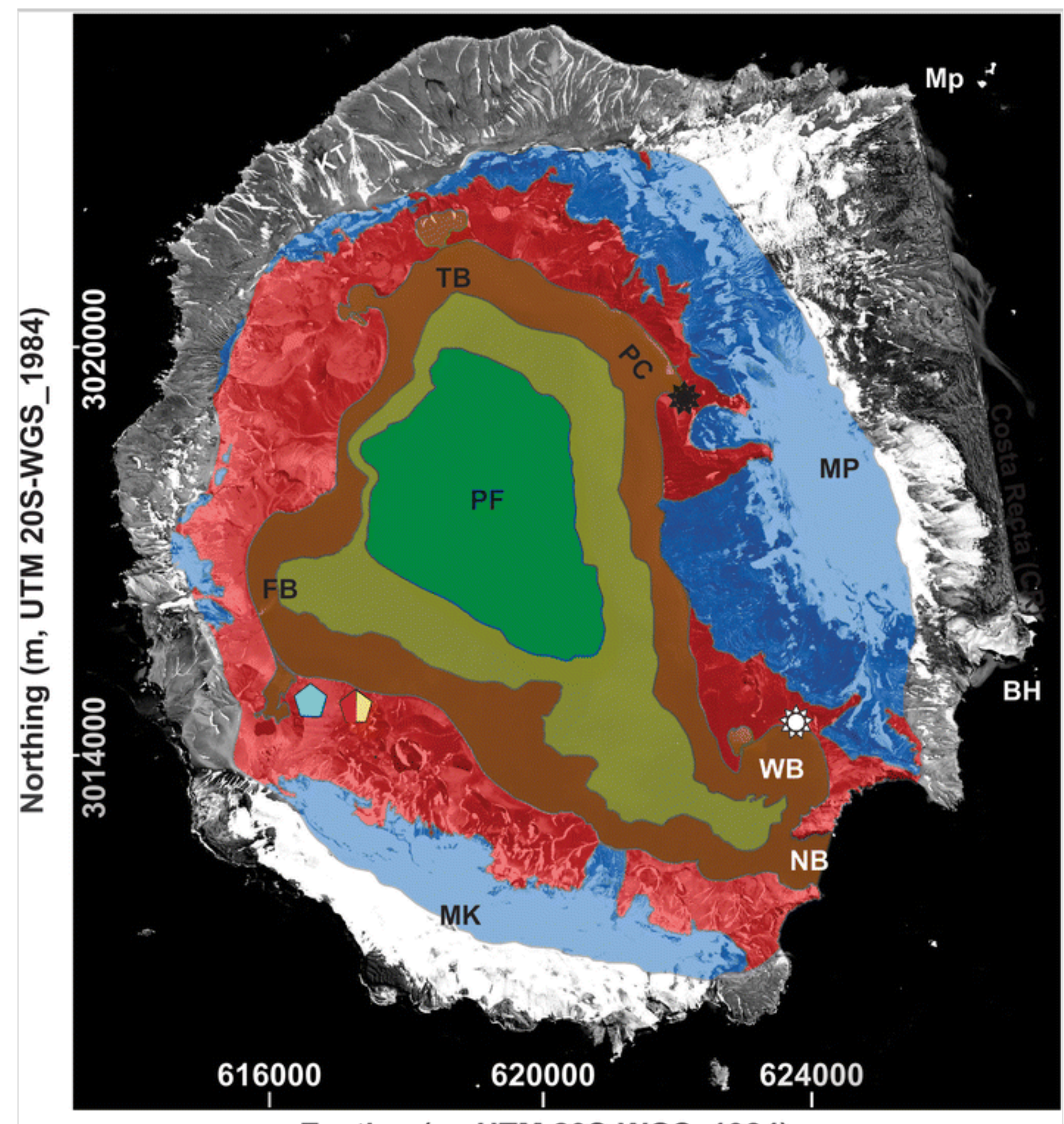

Easting (m, UTM 20S-WGS_1984)

E Land, magma-ice interaction. 1969-like eruption.

D Land, magma-aquifer interaction, 1967 and 1970 "land"-like eruption.

C Sea, 100 m b.s.l-0 m , shallow depth. Crimson-Hill, Kroner Lake and 1967, 1970 "island"-like eruption.

B Sea, 150-100 m b.s.l., intermediate depth. Submarine activity with possibility of Crimson Hill, Kroner Lake and 1967, 1970 "island"-like eruption.

A Sea, > $150 \mathrm{~m}$ b.s.l., great depth. Submarine activity. 
We are aware that the accuracy of our results depends on the quality of our field data and that further fieldwork is necessary at DI to better understand the dynamics of its post-caldera volcanism. In addition, our map presented in Fig. 14 does not allow precise forecasting guide of future eruptions, but it does serve as a useful reference to manage volcanic emergencies in case of a future eruption due to magma-water interaction. However, field conditions are challenging and exposure is limited, making the work presented here an important step in better defining the activity and associated hazard at this vulnerable location.

\section{Conclusions}

A detailed field revision was conducted on the historical volcanic episodes of Deception Island (Antarctica), with attention to Crimson Hill (1825-1829), Kroner Lake (1829-1912), and the 1967, 1969, and 1970 eruptions. These serve as representatives of the entire spectrum of potential hydrovolcanic activity on the island.

Volcanic activity during the Crimson Hill and Kroner Lake eruptions occurred in the shallow seawater of Whalers Bay. The Crimson Hill eruption shows a sequence dominated by turbulent dilute PDCs with activity occurring in shallow water or close to the shore of Pendulum Cove. The Kroner Lake eruption is mostly characterised by fallout deposits with no significant shift from hydrovolcanic to magmatic styles. The analysed samples are characterised by $\delta \mathrm{D}$ shifts toward oceanic values that reveal the influence of meteoric water derived from the sea and melted ice.

The 1967 and 1969 eruptions are characterised by clustered vents in shallow seawater or close to the coastline and are due to interaction with saturated or icy substrates. Field data from both eruptions suggest alternating volcanic and hydrovolcanic phases with fallout, ballistic blocks and bombs, and subordinate, dilute PDCs. Styles and hazards posed by volcanism on the island are therefore controlled by the location of the vents and the degree of magma interaction with the surrounding volcano-tectonic and water availability conditions. This work, therefore, shows how at DI, the location of a potential new eruptive vent can control magma-water interactions and the related hazards to be expected during a new eruption on the island. This is fundamental to better comprehend the potential evolution of a future hydrovolcanic eruption and therefore to improve the volcanic hazard assessment.

\section{Acknowledgments}

A.G. is grateful for her Ramón y Cajal contract (RYC-2012-11024). D.P. is grateful for his Beatriu de Pinós contract (2016 BP 00086). We thank the Associated Editor Jacopo Taddeucci, the Executive Editor Andrew Harris, and two anonymous reviewers for their constructive and supportive comments that significantly helped us to improve the manuscript. We thank all the military staff of the Spanish Antarctic Base Gabriel de Castilla for their constant help and for the logistic support, without which this research would not have been possible. We also thank the Laboratorio de Astronomía, Geodesia y Cartografía (Universidad de Cádiz) for providing the orthophotomap of Deception Island as well as the digital elevation model and the shape files of the geological map. English text was corrected by Dr. Grant George Buffett of Terranova Scientific.

Funding AQ20

This research was supported by the MICINN grant CTM2011-13578-E and was partially funded by the POSVOLDEC project (CTM2016-79617-P) (AEI/FEDER-UE). Analyses of stable isotopes were funded by the grant Programa Propio I (Usal-2014) through A.M.A-V.

\section{Electronic supplementary material}

\section{Supplementary Material 1}

UTM coordinates (Zone $20 \mathrm{~S}$ ) of stratigraphic logs of Figs. 2, 3, 5. (DOCX $16 \mathrm{~kb}$ )

\section{DEI55-C1}



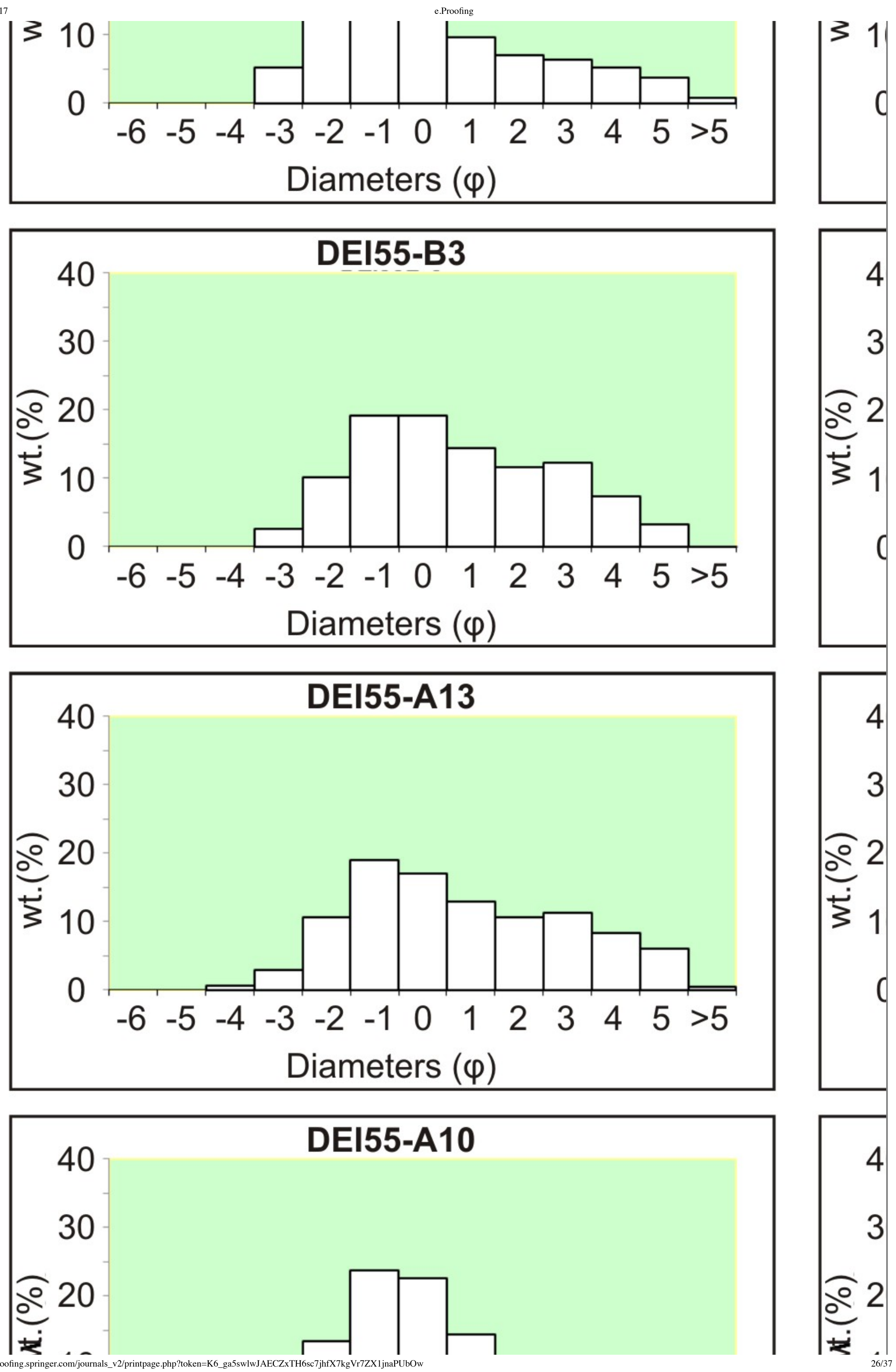


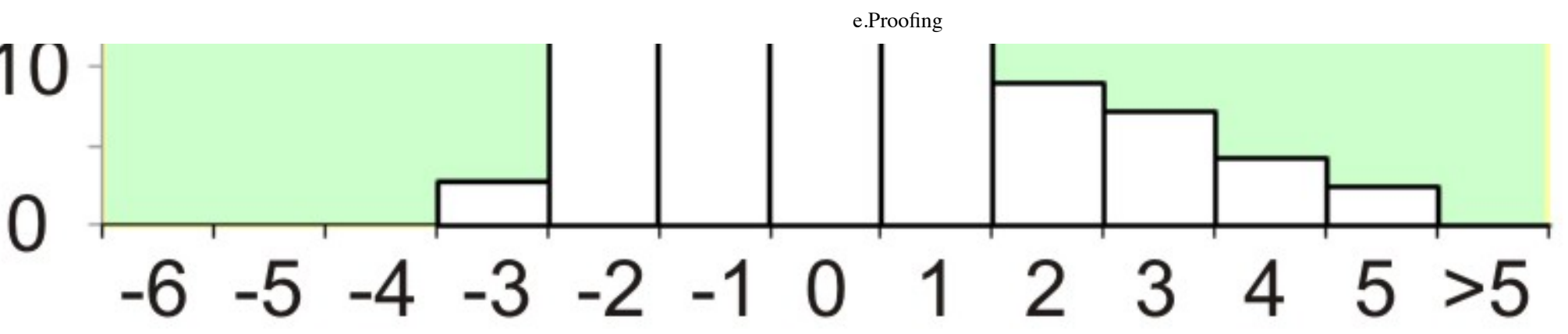

\section{Diameters $(\varphi)$}

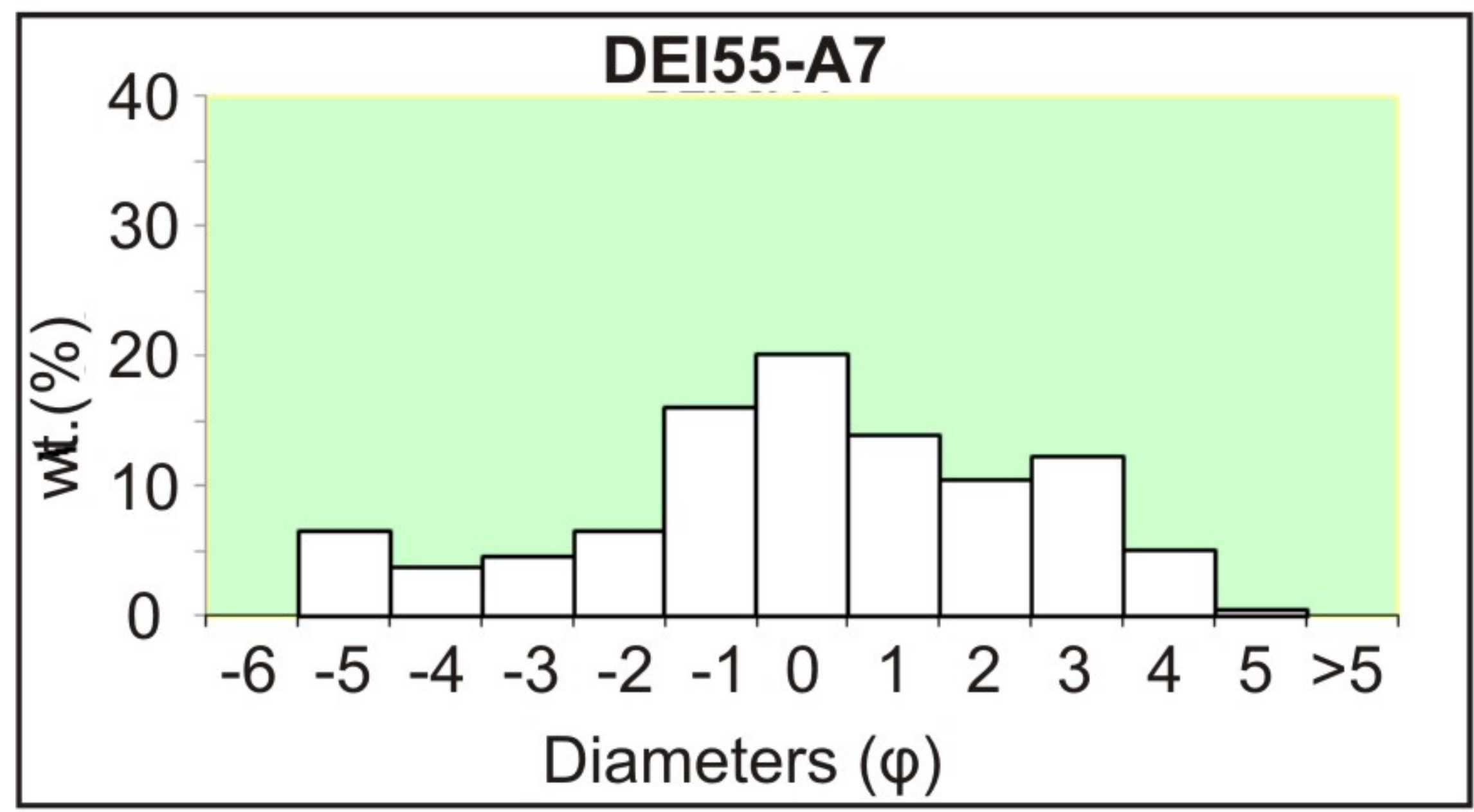

40

DEI55-A4

30

○20

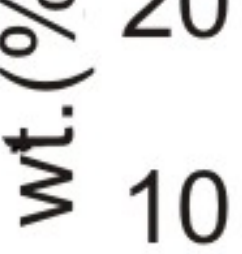

0

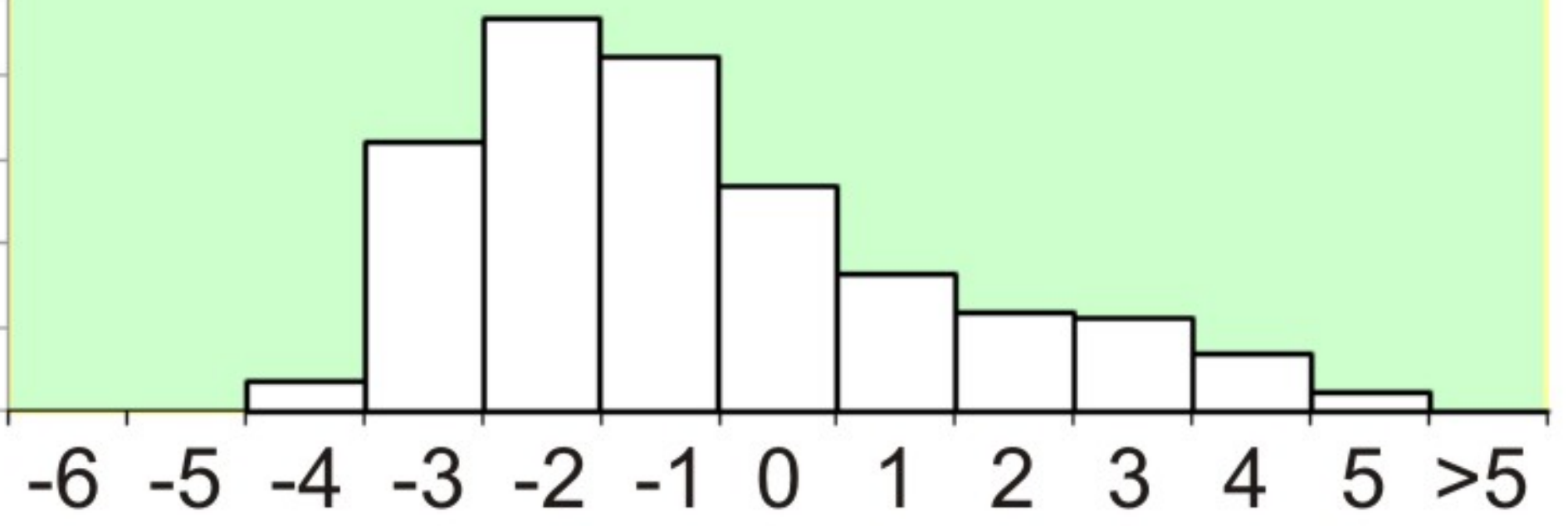

Diameters $(\varphi)$

40

DEI55-A1

30

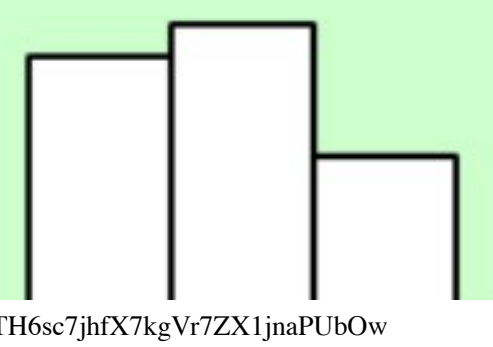

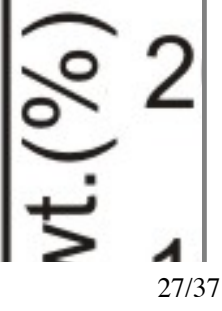




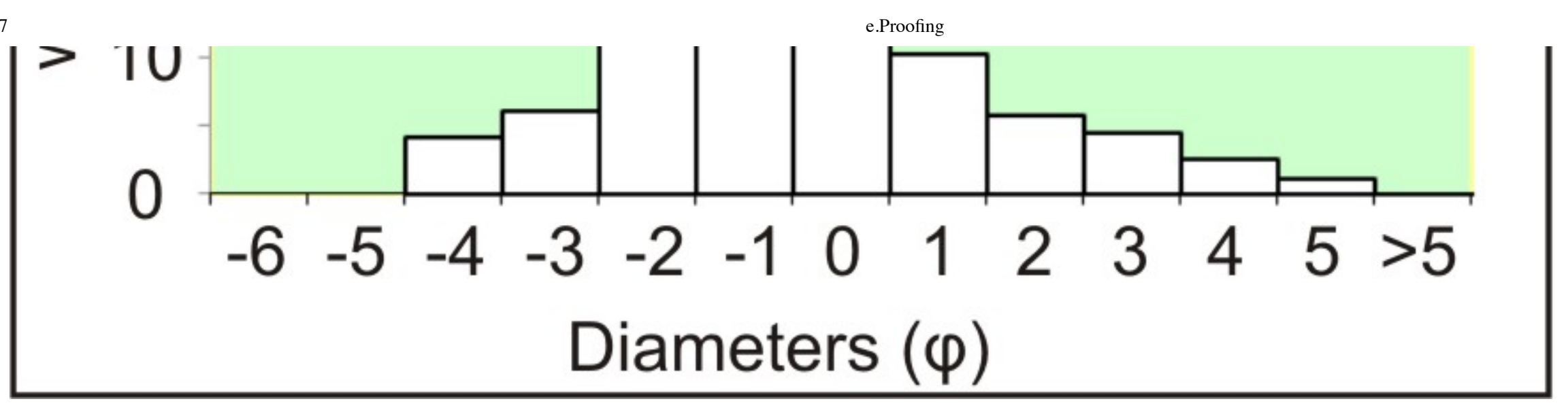

\section{Supplementary Material 2}

Grain Size analysis of Kroner Lake pyroclastic deposits. (JPEG 977 kb)
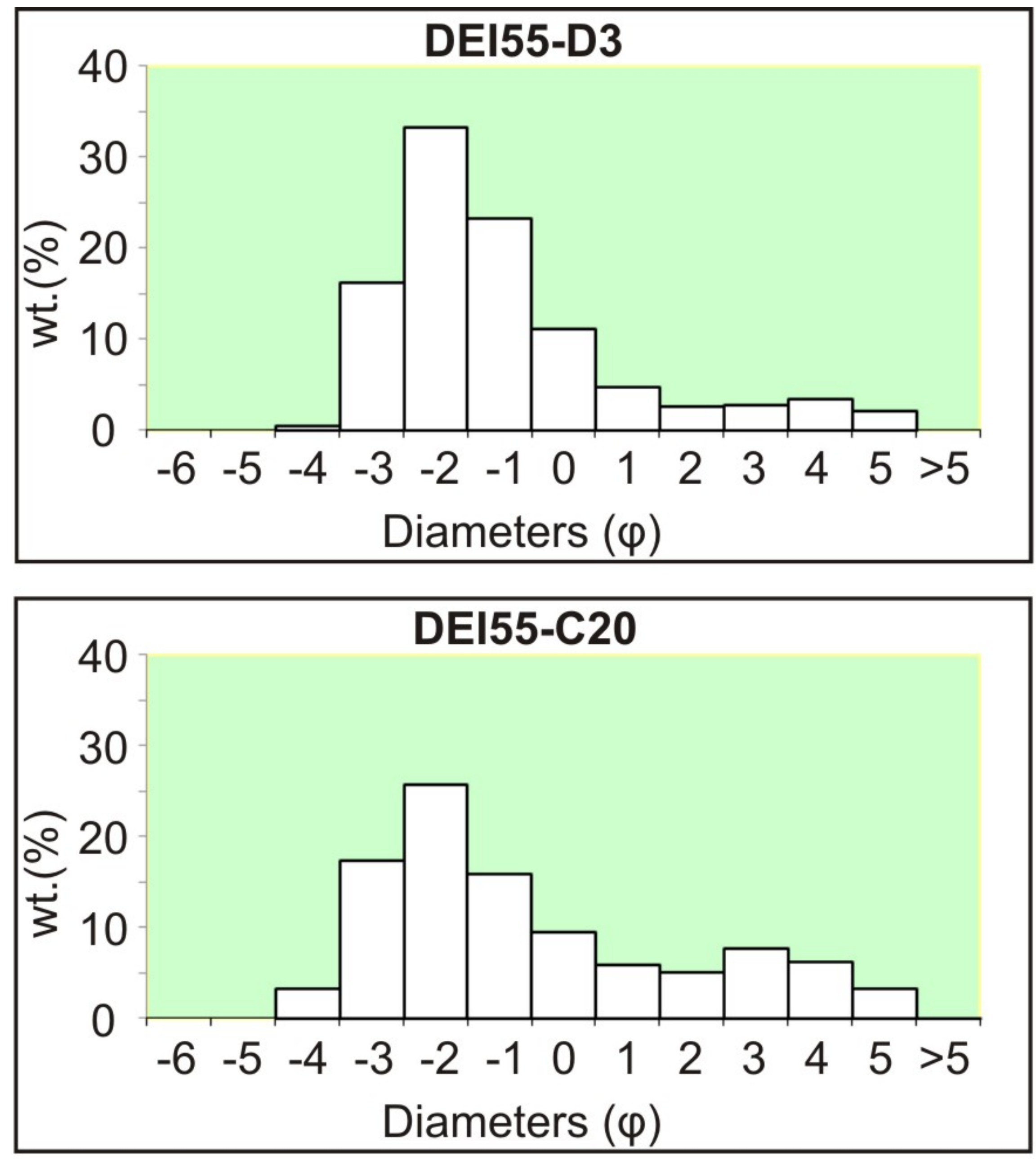

40

DEI55-C17

30 

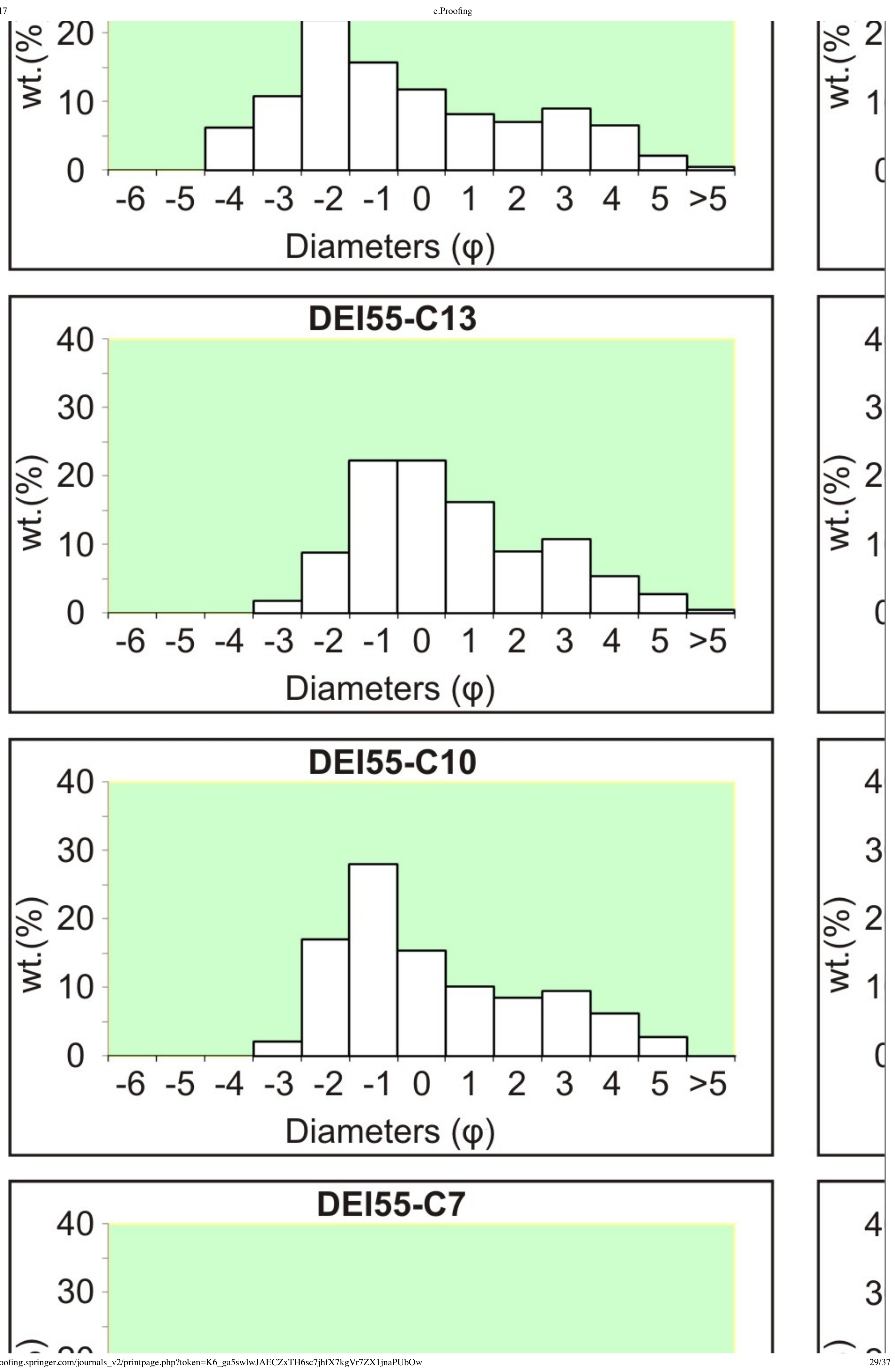

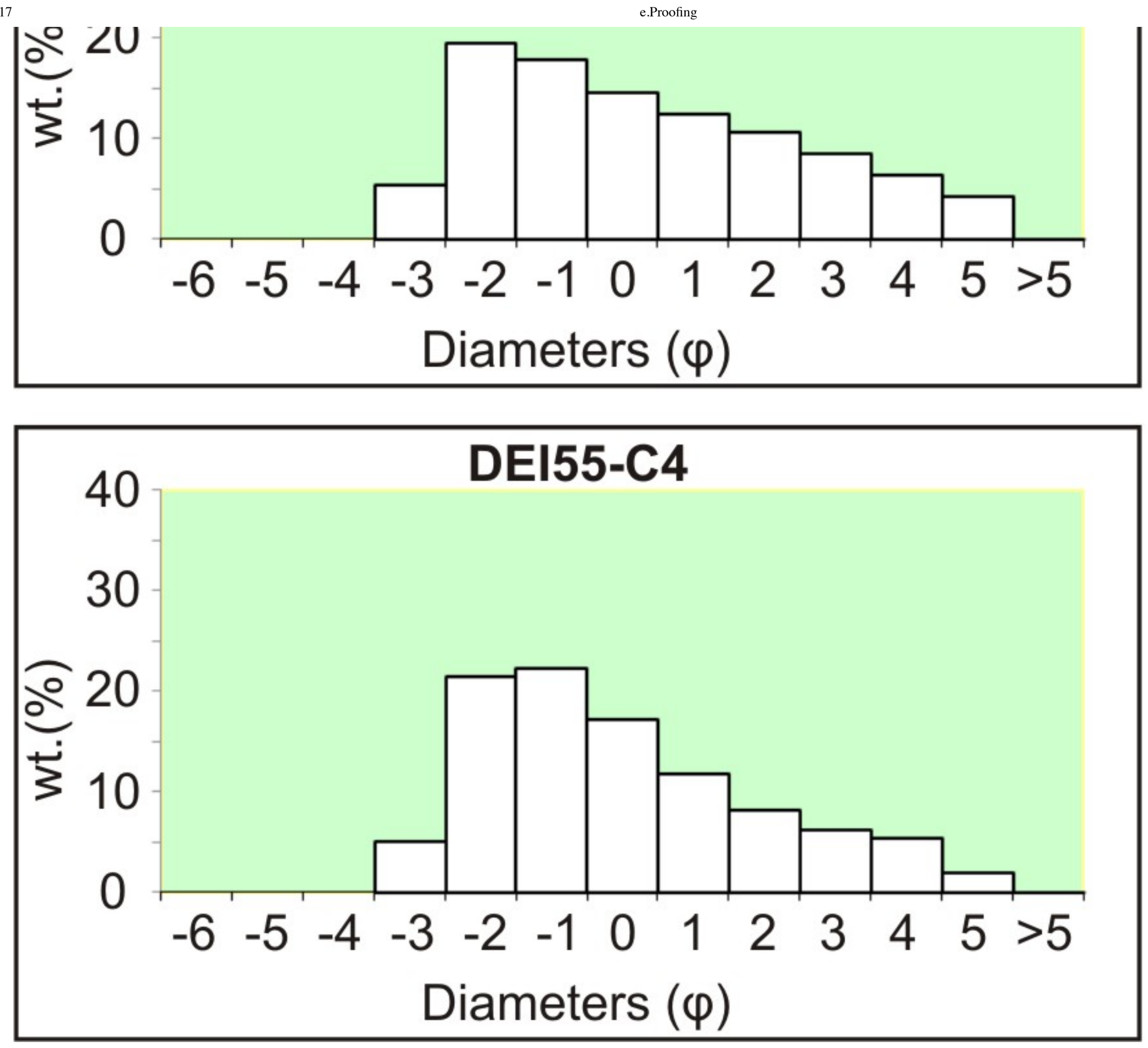

(JPEG $987 \mathrm{~kb})$

\section{Supplementary Material 3}

Selected representative rock samples of this study and geochemical data from previous papers. (XLSX $23 \mathrm{~kb}$ )

\section{References}

AQ21

Agustín-Flores J, Németh K, Cronin SJ, Lindsay JM, Kereszturi G, Brand BD, Smith IEM (2014) Phreatomagmatic eruptions through unconsolidated coastal plain sequences, Maungataketake, Auckland Volcanic Field (New Zealand). J Volcanol Geotherm Res 276(Supplement C):46-63

Agustín-Flores J, Németh K, Cronin SJ, Lindsay JM, Kereszturi G (2015a) Construction of the North Head (Maungauika) tuff cone: a product of Surtseyan volcanism, rare in the Auckland Volcanic Field, New Zealand. Bull Volcanol 77(2):11. https://doi.org/10.1007/s00445-014-0892-9

Agustín-Flores J, Németh K, Cronin SJ, Lindsay JM, Kereszturi G (2015b) Shallow-seated explosions in the construction of the Motukorea tuff ring (Auckland, New Zealand): evidence from lithic and sedimentary characteristics. J Volcanol Geotherm Res 304(Supplement C):272-286

Almendros J, Carmona E, Jiménez V, Díaz-Moreno A, Lorenzo F, Berrocoso M, de Gil A, Fernández-Ros A, Rosado B, Prates G, Peci LM (2015) Deception Island: sustained deformation and large increase in seismic activity during the 2014-2015 survey. Expert Group on Antarctic Volcanism (ANTVOLC). SCAR, Kickstart Meeting, Catania, Italy 
Aramaki S, Hayakawa Y, Fujii T, Nakamura K, Fukuoka T (1986) The October 1983 eruption of Miyakejima volcano. J Volcanol Geotherm Res 29(1):203-229. https://doi.org/10.1016/0377-0273(86)90045-4

Baker PE, McReath I (1971) Geological investigations on Deception Island. Antarct J US 6(4):85-86

Baker PE, McReath I, Harvey MR, Roobol MJ, Davies TG (1975) The geology of the South Shetland Islands. V. Volcanic evolution of Deception Island. British Antarctic Survey. 78:81 PP

Barclay AH, Wilcock WSD, Ibáñez JM (2008) Bathymetric constraints on the tectonic and volcanic evolution of Deception Island Volcano, South Shetland Islands. Antarct Sci 21(2):153-167

Bartolini S, Geyer A, Martí J, Pedrazzi D, Aguirre-Díaz G (2014) Volcanic hazard on Deception Island (South Shetland Islands, Antarctica). J Volcanol Geotherm Res 285(Supplement C):150-168

Bender NA, Crosbie K, Lynch HJ (2016) Patterns of tourism in the Antarctic Peninsula region: a 20-year analysis. Antarct Sci 28(3):194-203. https://doi.org/10.1017/S0954102016000031

Bigeleisen J, Perlman ML, Prosser HC (1952) Conversion of hydrogenic materials to hydrogen for isotopic analysis. Anal Chem 24(8):1356-1357. https://doi.org/10.1021/ac60068a025

Bindeman I (2008) Oxygen isotopes in mantle and crustal magmas as revealed by single crystal analysis. Rev Mineral Geochem 69(1):445-478. https://doi.org/10.2138/rmg.2008.69.12

Björnsson H (2003) Subglacial lakes and jökulhlaups in Iceland. Glob Planet Chang 35(3):255-271. https://doi.org/10.1016/S0921-8181(02)00130-3

Blaikie TN, van Otterloo J, Ailleres L, Betts PG, Cas RAF (2015) The erupted volumes of tephra from maar volcanoes and estimates of their VEI magnitude: Examples from the late Cenozoic Newer Volcanics Province, south-eastern Australia. J Volcanol Geotherm Res 301(Supplement C):81-89

Bonadonna C, Costa A (2013) Plume height, volume, and classification of explosive volcanic eruptions based on the Weibull function. Bull Volcanol 75(8):742. https://doi.org/10.1007/s00445-013-0742-1

Breard ECP, Lube G, Cronin SJ, Valentine GA (2015) Transport and deposition processes of the hydrothermal blast of the 6 August 2012 Te Maari eruption, Mt. Tongariro. Bull Volcanol 77(11):100. https://doi.org/10.1007/s00445-0150980-5

Brenna M, Németh K, Cronin SJ, Sohn YK, Smith IEM, Wijbrans J (2015) Co-located monogenetic eruptions 200 kyr apart driven by tapping vertically separated mantle source regions, Chagwido, Jeju Island, Republic of Korea. Bull Volcanol 77(5):43. https://doi.org/10.1007/s00445-015-0928-9

Büttner R, Zimanowski B, Mohrholz C-O, Kümmel R (2005) Analysis of thermohydraulic explosion energetics. J Appl Phys 98(4):043524. https://doi.org/10.1063/1.2033149

Carmona J, Romero C, Dóniz J, García A (2011) Characterization and facies analysis of the hydrovolcanic deposits of Montaña Pelada tuff ring: Tenerife, Canary Islands. J Afr Earth Sci 59(1):41-50.

https://doi.org/10.1016/j.jafrearsci.2010.07.003

Carrivick JL (2007) Hydrodynamics and geomorphic work of jökulhlaups (glacial outburst floods) from Kverkfjöll volcano, Iceland. Hydrol Process 21(6):725-740. https://doi.org/10.1002/hyp.6248

Carrivick JL, Russell AJ, Tweed FS (2004) Geomorphological evidence for jökulhlaups from Kverkfjöll volcano, Iceland. Geomorphology 63(1):81-102. https://doi.org/10.1016/j.geomorph.2004.03.006

Cas RAF, Wright JV (1987) Volcanic successions, modern and ancient. A geological approach to processes products and successions. $528 \mathrm{pp}$

Clarke H, Troll VR, Carracedo JC (2009) Phreatomagmatic to Strombolian eruptive activity of basaltic cinder cones: Montaña Los Erales, Tenerife, Canary Islands. J Volcanol Geotherm Res 180(2):225-245.

https://doi.org/10.1016/j.jvolgeores.2008.11.014 
Clayton RN, Mayeda TK (1963) The use of bromine pentafluoride in the extraction of oxygen from oxides and silicates for isotopic analysis. Geochim Cosmochim Acta 27(1):43-52. https://doi.org/10.1016/0016-7037(63)90071-1

Cole P, Guest J, Duncan A, Pacheco J (2001) Capelinhos 1957-1958, Faial, Azores: deposits formed by an emergent Surtseyan eruption. Bull Volcanol 63(2):204-220. https://doi.org/10.1007/s004450100136

Cole PD, Neri A, Baxter PJ (2015) Hazards from pyroclastic density currents. In: Sigurdsson H, Houghton BF, McNutt SR, Rymer H, Stix J (eds) Encyclopedia of volcanoes. Academic Press, San Diego, pp 943-956.

https://doi.org/10.1016/B978-0-12-385938-9.00054-7

Connor CB, Conway FM (2000) Basaltic volcanic fields. In: Sigurdsson H (ed) Encyclopedia of volcanoes. Academic Press, San Francisco, pp 331-343

Dalziel IWD (1984) Tectonic evolution of a forearc terrane, southern Scotia Ridge, Antarctica. In: Dalziel IWD (ed) Tectonic evolution of a forearc terrane. Geological Society of America, Southern Scotia Ridge. https://doi.org/10.1130/SPE200-p1

De La Nuez J, Alonso J, Quesada M, Macu M (1993) Edificios hidromagmáticos costeros de Tenerife (Islas Canarias). Rev Soc Geol España 6(1-2):47-59

De Silva S, Lindsay JM (2015) Primary volcanic landforms. In Sigurdsson, Haraldur, et al., eds. The encyclopedia of volcanoes. Elsevier: 273-297. doi: https://doi.org/10.1016/B978-0-12-385938-9.00015-8

Eagles G (2004) Tectonic evolution of the Antarctic-Phoenix plate system since 15 Ma. Earth Planet Sci Lett 217(1):97109. https://doi.org/10.1016/S0012-821X(03)00584-3

Fretzdorff S, Smellie JL (2003) Electron microprobe characterization of ash layers in sediments from the central Bransfield basin (Antarctic Peninsula): evidence for at least two volcanic sources. Antarct Sci 14(4):412-421

Geerts B, Linacre E (1997) Sunspots and climate. Reproduced at uwyo. edu, 1997 - http://www-das.uwyo.edu

Godfrey JD (1962) The deuterium content of hydrous minerals from the East-Central Sierra Nevada and Yosemite National Park. Geochim Cosmochim Acta 26(12):1215-1245. https://doi.org/10.1016/0016-7037(62)90053-4

González-Ferrán O, Munizafa F, Moreno H (1971) Sintesis de la evolución volcánica de Isla Decepción y la erupción de 1970. Instituto Antártico Chileno Serie Científicas 2:1-14

Gràcia E, Canals M, Lí Farràn M, José Prieto M, Sorribas J, Team G (1996) Morphostructure and evolution of the central and eastern Bransfield basins (NW Antarctic Peninsula). Mar Geophys Res 18(2):429-448. https://doi.org/10.1007/BF00286088

Grad M, Guterch A, Środa P (2004) Upper crustal structure of Deception Island area, Bransfield Strait, West Antarctica. Antarct Sci 4(4):469-476

Graettinger AH, Valentine GA, Sonder I, Ross PS, White JDL, Taddeucci J (2014) Maar-diatreme geometry and deposits: subsurface blast experiments with variable explosion depth. Geochem Geophys Geosyst 15(3):740-764. https://doi.org/10.1002/2013GC005198

Graettinger AH, Valentine GA, Sonder I (2015a) Circum-crater variability of deposits from discrete, laterally and vertically migrating volcanic explosions: Experimental evidence and field implications. J Volcanol Geotherm Res 308(Supplement C):61-69

Graettinger AH, Valentine GA, Sonder I, Ross P-S, White JDL (2015b) Facies distribution of ejecta in analog tephra rings from experiments with single and multiple subsurface explosions. Bull Volcanol 77(8):66.

https://doi.org/10.1007/s00445-015-0951-x

Gudmundsson G (2011) Respiratory health effects of volcanic ash with special reference to Iceland. A review. Clin Respir J 5(1):2-9. https://doi.org/10.1111/j.1752-699X.2010.00231.x

Gudmundsson MT, Sigmundsson F, Björnsson H (1997) Ice-volcano interaction of the 1996 Gjálp subglacial eruption, Vatnajökull, Iceland. Nature 389(6654):954-957. https://doi.org/10.1038/40122 
Hawkes DD (1961) The geology of the South Shetland Islands: II. The geology and petrology of Deception Island 27 (HMSO)

Horwell CJ, Baxter PJ (2006) The respiratory health hazards of volcanic ash: a review for volcanic risk mitigation. Bull Volcanol 69(1):1-24. https://doi.org/10.1007/s00445-006-0052-y

Houghton B, Carey RJ (2015) Pyroclastic fall deposits. In: Sigurdsson H, Houghton B, Rymer H, Stix J, MeNutt S (eds) Encyclopedia of volcanoes. Elsevier Inc, United Kingdom, pp 599616

Houghton BF, Hackett WR (1984) Strombolian and phreatomagmatic deposits of Ohakune craters, Ruapehu, New Zealand: a complex interaction between external water and rising basaltic magma. J Volcanol Geotherm Res 21(34):207-231. https://doi.org/10.1016/0377-0273(84)90023-4

Ibáñez JM, Almendros J, Carmona E, Martí C, Abril M (2003) The recent seismo-volcanic activity at Deception Island volcano. Deep-Sea Res II Top Stud Oceanogr 50(10):1611-1629. https://doi.org/10.1016/S0967-0645(03)00082-1

Irvine TN, Baragar WRA (1971) A guide to the chemical classification of the common volcanic rocks. Can J Earth Sci 8(5):523-548. https://doi.org/10.1139/e71-055

Jeffers J, Anderson J (1990) Sequence stratigraphy of the Bransfield Basin, Antarctica: implications for tectonic history and hydrocarbonpotential In: St. John B (ed) Antarctica as an exploration frontier: hydrocarbon potential, geology and hazards Am Ass Petrol Geol Stud Geol 31:13-29

Keller RA, Fisk MR, White WM, Birkenmajer K (1992) Isotopic and trace element constraints on mixing and melting models of marginal basin volcanism, Bransfield Strait, Antarctica. Earth Planet Sci Lett 111(2):287-303. https://doi.org/10.1016/0012-821X(92)90185-X

Kendal L (1831) Account of the island of deception, one of the New Shetland Isles. J R Geogr Soc Lond 1:62-66

Kereszturi G, Németh K (2012) Monogenetic basaltic volcanoes: genetic classification, growth, geomorphology and degradation. In: Nemeth K (ed) Updates in volcanology_new advances in understanding volcanic systems. InTech, Rijeka, p Ch. 1

Kereszturi G, Németh K, Cronin SJ, Agustín-Flores J, Smith IEM, Lindsay J (2013) A model for calculating eruptive volumes for monogenetic volcanoes - implication for the Quaternary Auckland Volcanic Field, New Zealand. J Volcanol Geotherm Res 266(Supplement C):16-33

Kereszturi G, Németh K, Cronin SJ, Procter J, Agustín-Flores J (2014) Influences on the variability of eruption sequences and style transitions in the Auckland Volcanic Field, New Zealand. J Volcanol Geotherm Res 286(Supplement C):101-115

Kereszturi G, Bebbington M, Németh K (2017) Forecasting transitions in monogenetic eruptions using the geologic record. Geology 45(3):283-286. https://doi.org/10.1130/G38596.1

Kienle J, Kyle PR, Self S, Motyka RJ, Lorenz V (1980) Ukinrek Maars, Alaska, I. April 1977 eruption sequence, petrology and tectonic setting. J Volcanol Geotherm Res 7(1):11-37. https://doi.org/10.1016/0377-0273(80)90018-9

Lawver LA, Keller RA, Fisk MR, Strelin JA (1995) Bransfield Strait, Antarctic Peninsula active extension behind a dead arc. In: Taylor B (ed) Backarc basins: tectonics and magmatism. Springer US, Boston, MA, pp 315-342. doi: https://doi.org/10.1007/978-1-4615-1843-3_8

Le Bas MJ, Le Maitre RW, Streckeisen A, Zanettin B (1986) A chemical classification of volcanic rocks based on the total alkali-silica diagram. J Petrol 27(3):745-750. https://doi.org/10.1093/petrology/27.3.745

Lorenz V (1986) On the growth of maars and diatremes and its relevance to the formation of tuff rings. Bull Volcanol 48(5):265-274. https://doi.org/10.1007/BF01081755

Lorenz V (2003) Maar-diatreme volcanoes, their formation, and their setting in hard-rock or soft-rock environments. GeoLines 15:72-83 
Lorenz V, Suhr P, Suhr S (2017) Phreatomagmatic maar-diatreme volcanoes and their incremental growth: a model. Geol Soc Lond, Spec Publ 446(1):29-59. https://doi.org/10.1144/SP446.4

Machado F, Parsons WH, Richards AF, Mulford JW (1962) Capelinhos eruption of Fayal Volcano, Azores, 1957-1958. J Geophys Res 67(9):3519-3529. https://doi.org/10.1029/JZ067i009p03519

Macorps É, Graettinger AH, Valentine GA, Ross P-S, White JDL, Sonder I (2016) The effects of the host-substrate properties on maar-diatreme volcanoes: experimental evidence. Bull Volcanol 78(4):26. https://doi.org/10.1007/s00445016-1013-8

Maeno F, Nakada S, Oikawa T, Yoshimoto M, Komori J, Ishizuka Y, Takeshita Y, Shimano T, Kaneko T, Nagai M (2016) Reconstruction of a phreatic eruption on 27 September 2014 at Ontake volcano, central Japan, based on proximal pyroclastic density current and fallout deposits. Earth Planets Space 68(1):82. https://doi.org/10.1186/s40623-016-04496

Martí J, Planagumà L, Geyer A, Canal E, Pedrazzi D (2011) Complex interaction between Strombolian and phreatomagmatic eruptions in the Quaternary monogenetic volcanism of the Catalan Volcanic Zone (NE of Spain). J Volcanol Geotherm Res 201(1):178-193. https://doi.org/10.1016/j.jvolgeores.2010.12.009

Martí J, Geyer A, Aguirre-Diaz G (2013) Origin and evolution of the Deception Island caldera (South Shetland Islands, Antarctica). Bull Volcanol 75(6):732. https://doi.org/10.1007/s00445-013-0732-3

Moreton SG, Smellie JL (1998) Identification and correlation of distal tephra layers in deep-sea sediment cores, Scotia Sea, Antarctica. Ann Glaciol 27(1):285-289. https://doi.org/10.3189/1998AoG27-1-285-289

Needham AJ, Lindsay JM, Smith IEM, Augustinus P, Shane PA (2011) Sequential eruption of alkaline and sub-alkaline magmas from a small monogenetic volcano in the Auckland Volcanic Field, New Zealand. J Volcanol Geotherm Res 201(1-4):126-142. https://doi.org/10.1016/j.jvolgeores.2010.07.017

Németh K, Cronin SJ (2007) Syn- and post-eruptive erosion, gully formation, and morphological evolution of a tephra ring in tropical climate erupted in 1913 in West Ambrym, Vanuatu. Geomorphology 86(1):115-130.

https://doi.org/10.1016/j.geomorph.2006.08.016

Németh K, Cronin SJ (2009) Phreatomagmatic volcanic hazards where rift-systems meet the sea, a study from Ambae Island, Vanuatu. J Volcanol Geotherm Res 180(2):246-258. https://doi.org/10.1016/j.jvolgeores.2008.08.011

Németh K, Cronin SJ (2011) Drivers of explosivity and elevated hazard in basaltic fissure eruptions: the 1913 eruption of Ambrym Volcano, Vanuatu (SW-Pacific). J Volcanol Geotherm Res 201(1-4):194-209.

https://doi.org/10.1016/j.jvolgeores.2010.12.007

Németh K, Kereszturi G (2015) Monogenetic volcanism: personal views and discussion. Int J Earth Sci 104(8):21312146. https://doi.org/10.1007/s00531-015-1243-6

Newhall CG, Self S (1982) The volcanic explosivity index (VEI) an estimate of explosive magnitude for historical volcanism. J Geophys Res: Oceans 87(C2):1231-1238. https://doi.org/10.1029/JC087iC02p01231

Oliva-Urcia B, Gil-Peña I, Maestro A, López-Martínez J, Galindo-Zaldívar J, Soto R, Gil-Imaz A, Rey J, Pueyo O (2016) Paleomagnetism from Deception Island (South Shetlands archipelago, Antarctica), new insights into the interpretation of the volcanic evolution using a geomagnetic model. Int J Earth Sci 105(5):1353-1370.

https://doi.org/10.1007/s00531-015-1254-3

Orheim O (1971) Volcanic activity on Deception Island, South Shetland Islands. In: ADIE RJ (ed) Antarctic geology and geophysics. Universitetsforlaget, Oslo, pp 117-120

Orheim O (1972) Volcanic activity on Deception Island, South Shetland Islands. Ohio State University, Institute of Polar Studies

Palladino D, Valentine G, Sottili G, Taddeucci J (2015) Maars to calderas: end-members on a spectrum of explosive volcanic depressions. Front Earth Sci 3(36) 
Pardo N, Macias JL, Giordano G, Cianfarra P, Avellán DR, Bellatreccia F (2009) The 1245 yr BP Asososca maar eruption: the youngest event along the Nejapa-Miraflores volcanic fault, Western Managua, Nicaragua. J Volcanol Geotherm Res 184(3-4):292-312. https://doi.org/10.1016/j.jvolgeores.2009.04.006

Pardo N, Cronin SJ, Németh K, Brenna M, Schipper CI, Breard E, White JDL, Procter J, Stewart B, Agustín-Flores J, Moebis A, Zernack A, Kereszturi G, Lube G, Auer A, Neall V, Wallace C (2014) Perils in distinguishing phreatic from phreatomagmatic ash; insights into the eruption mechanisms of the 6 August 2012 Mt. Tongariro eruption, New Zealand. J Volcanol Geotherm Res 286(Supplement C):397-414

Parfitt EA (2004) A discussion of the mechanisms of explosive basaltic eruptions. J Volcanol Geotherm Res 134(1):77107. https://doi.org/10.1016/j.jvolgeores.2004.01.002

Peccerillo A, Tripodo A, Villari L, Currieri S, Zimbalaiti E (1991) Genesis and evolution of volcanism in back-arc areas. A case history, the Island of Deception (Western Antarctica). Periodico di Mineral 60(1-3):29-44

Pedrazzi D, Martí J, Geyer A (2013) Stratigraphy, sedimentology and eruptive mechanisms in the tuff cone of El Golfo (Lanzarote, Canary Islands). Bull Volcanol 75(7):740. https://doi.org/10.1007/s00445-013-0740-3

Pedrazzi D, Aguirre-Díaz G, Bartolini S, Martí J, Geyer A (2014c) The 1970 eruption on Deception Island (Antarctica): eruptive dynamics and implications for volcanic hazards. J Geol Soc 171(6):765-778.

https://doi.org/10.1144/jgs2014-015

Prata F, Rose B (2015) Volcanic ash hazards to aviation. In: Sigurdsson H, Houghton BF, McNutt SR, Rymer H, Stix J (eds) Encyclopedia of volcanoes. Academic Press, San Diego, pp 911-934. https://doi.org/10.1016/B978-0-12-3859389.00052-3

Roach P (1978) Nature of back-arc extension in bransfield strait. In Geophysical Journal of the Royal Astronomical Society (Vol. 53, No. 1, pp. 165-165) osney mead, oxford, oxon, england ox2 0el: blackwell science ltd

Roobol MJ (1973) Historic volcanic activity at Deception Island. Brit Antarct Surv Bull 32:23-30

Roobol MJ (1980) A model for the eruptive mechanism of Deception Island from 1820 to 1970. Brit Antarct Surv Bull 49:137-156

Ross P-S, Delpit S, Haller MJ, Németh K, Corbella H (2011) Influence of the substrate on maar-diatreme volcanoes-an example of a mixed setting from the Pali Aike volcanic field, Argentina. J Volcanol Geotherm Res 201(1-4):253-271. https://doi.org/10.1016/j.jvolgeores.2010.07.018

Rottas KM, Houghton BF (2012) Structure, stratigraphy, and eruption dynamics of a young tuff ring: Hanauma Bay, O’ahu, Hawai'i. Bull Volcanol 74(7):1683-1697. https://doi.org/10.1007/s00445-012-0624-y

Schipper CI, White JDL, Zimanowski B, Büttner R, Sonder I, Schmid A (2011) Experimental interaction of magma and “dirty" coolants. Earth Planet Sci Lett 303(3):323-336. https://doi.org/10.1016/j.eps1.2011.01.010

Self S, Kienle J, Huot J-P (1980) Ukinrek Maars, Alaska, II. Deposits and formation of the 1977 craters. J Volcanol Geotherm Res 7(1):39-65. https://doi.org/10.1016/0377-0273(80)90019-0

Sheridan MF, Wohletz KH (1983) Hydrovolcanism: basic considerations and review. J Volcanol Geotherm Res 17(1):129. https://doi.org/10.1016/0377-0273(83)90060-4

Shultz CH (1972) Eruption at Deception Island, Antarctica, August 1970. GSA Bull 83(9):2837-2842.

https://doi.org/10.1130/0016-7606(1972)83[2837:EADIAA]2.0.CO;2

Smellie JL (1988) Recent observations on the volcanic history of Deception Island, South Shetland Islands. Brit Antarct Surv Bull 81:83

Smellie JL (1999) The upper Cenozoic tephra record in the south polar region: a review. Glob Planet Chang 21(1):5170. https://doi.org/10.1016/S0921-8181(99)00007-7 
Smellie JL (2001) Lithostratigraphy and volcanic evolution of Deception Island, South Shetland Islands. Antarct Sci 73(2):788-209

Smellie JL (2002) The 1969 subglacial eruption on Deception Island (Antarctica): events and processes during an eruption beneath a thin glacier and implications for volcanic hazards. Geol Soc Lond, Spec Publ 202(1):59-79. https://doi.org/10.1144/GSL.SP.2002.202.01.04

Smellie JL, López-Martínez J, Headland RK, Hernández-Cifuentes F, Maestro A, Millar IL, Rey J, Serrano E, Somoza L, Thomson JW (2002) Geology and geomorphology of Deception Island. (BAS Geomap Series, Sheets 6A and 6B).77pp

Smith IEM, Németh K (2017) Source to surface model of monogenetic volcanism: a critical review. Geol Soc Lond, Spec Publ 446(1):1-28. https://doi.org/10.1144/SP446.14

Sohn YK, Chough SK (1989) Depositional processes of the Suwolbong tuff ring, Cheju Island (Korea). Sedimentology 36(5):837-855. https://doi.org/10.1111/j.1365-3091.1989.tb01749.x

Sohn YK, Park KH (2005) Composite tuff ring/cone complexes in Jeju Island, Korea: possible consequences of substrate collapse and vent migration. J Volcanol Geotherm Res 141(1-2):157-175.

https://doi.org/10.1016/j.jvolgeores.2004.10.003

Sohn YK, Park JB, Khim BK, Park KH, Koh GW (2003) Stratigraphy, petrochemistry and Quaternary depositional record of the Songaksan tuff ring, Jeju Island, Korea. J Volcanol Geotherm Res 119(1):1-20.

https://doi.org/10.1016/S0377-0273(02)00302-5

Sohn YK, Cronin SJ, Brenna M, Smith IEM, Németh K, White JDL, Murtagh RM, Jeon YM, Kwon CW (2012) Ilchulbong tuff cone, Jeju Island, Korea, revisited: a compound monogenetic volcano involving multiple magma pulses, shifting vents, and discrete eruptive phases. GSA Bull 124(3-4):259-274. https://doi.org/10.1130/B30447.1

Solgevik H, Mattsson HB, Hermelin O (2007) Growth of an emergent tuff cone: fragmentation and depositional processes recorded in the Capelas tuff cone, São Miguel, Azores. J Volcanol Geotherm Res 159(1):246-266. https://doi.org/10.1016/j.jvolgeores.2006.06.020

Sonder I, Graettinger AH, Valentine GA (2015) Scaling multiblast craters: general approach and application to volcanic craters. J Geophys Res: Solid Earth 120(9):6141-6158

Sottili G, Taddeucci J, Palladino DM, Gaeta M, Scarlato P, Ventura G (2009) Sub-surface dynamics and eruptive styles of maars in the Colli Albani Volcanic District, Central Italy. J Volcanol Geotherm Res 180(2-4):189-202.

https://doi.org/10.1016/j.jvolgeores.2008.07.022

Sottili G, Palladino DM, Gaeta M, Masotta M (2012) Origins and energetics of maar volcanoes: examples from the ultrapotassic Sabatini Volcanic District (Roman Province, Central Italy). Bull Volcanol 74(1):163-186. https://doi.org/10.1007/s00445-011-0506-8

Stroncik NA, Schmincke H-U (2002) Palagonite-a review. Int J Earth Sci 91(4):680-697. https://doi.org/10.1007/s00531-001-0238-7

Taylor Jr HP (1967) Oxygen isotope studies of hydrothermal mineral deposits. Geochemistry of hydrothermal ore deposits:109-142

Torrecillas C, Berrocoso M, García-García A (2006) The Multidisciplinary Scientific Information Support System (SIMAC) for Deception Island. In: Fütterer DK, Damaske D, Kleinschmidt G, Miller H, Tessensohn F (eds) Antarctica: contributions to global earth sciences. Springer Berlin Heidelberg, Berlin, pp 397-402. https://doi.org/10.1007/3-54032934-X_50

Valencio DA, Mendía J, Vilas JF (1979) Palaeomagnetism and KAr age of Mesozoic and Cenozoic igneous rocks from Antarctica. Earth Planet Sci Lett 45(1):61-68. https://doi.org/10.1016/0012-821X(79)90107-9

Valentine GA, Graettinger AH, Sonder I (2014) Explosion depths for phreatomagmatic eruptions. Geophys Res Lett 41(9):3045-3051. https://doi.org/10.1002/2014GL060096 
Valentine GA, Graettinger AH, Macorps É, Ross P-S, White JDL, Döhring E, Sonder I (2015a) Experiments with vertically and laterally migrating subsurface explosions with applications to the geology of phreatomagmatic and hydrothermal explosion craters and diatremes. Bull Volcanol 77(3):15. https://doi.org/10.1007/s00445-015-0901-7

Valentine GA, Sottili G, Palladino DM, Taddeucci J (2015b) Tephra ring interpretation in light of evolving maardiatreme concepts: Stracciacappa maar (central Italy). J Volcanol Geotherm Res 308(Supplement C):19-29

Verwoerd WJ, Chevallier L (1987) Contrasting types of Surtseyan tuff cones on Marion and Prince Edward islands, southwest Indian Ocean. Bull Volcanol 49(1):399-413. https://doi.org/10.1007/BF01046633

Vespermann D, Schmincke HU (2000) Scoria cones and tuff rings. In: Sigurdsson H, Houghton BF, McNutt SR, Rymer H, Stix J (eds) Encyclopedia of volcanoes. Academic Press, San Diego, pp 683-694

Vuan A, Robertson Maurice SD, Wiens DA, Panza GF (2005) Crustal and upper mantle S-wave velocity structure beneath the Bransfield Strait (West Antarctica) from regional surface wave tomography. Tectonophysics 397(3):241259. https://doi.org/10.1016/j.tecto.2004.12.011

Walker GPL (2000) Basaltic volcanoes and volcanic systems. In: Sigurdsson H (ed) Encyclopedia of volcanoes. Academic Press, San Francisco, pp 283-289

White JDL (1996) Impure coolants and interaction dynamics of phreatomagmatic eruptions. J Volcanol Geotherm Res 74(3):155-170. https://doi.org/10.1016/S0377-0273(96)00061-3

White JDL, Houghton BF (2006) Primary volcaniclastic rocks. Geology 34(8):677-680. https://doi.org/10.1130/G22346.1

White JDL, Ross PS (2011) Maar-diatreme volcanoes: a review. J Volcanol Geotherm Res 201(1):1-29. https://doi.org/10.1016/j.jvolgeores.2011.01.010

White JDL, Schmincke H-U (1999) Phreatomagmatic eruptive and depositional processes during the 1949 eruption on La Palma (Canary Islands). J Volcanol Geotherm Res 94(1):283-304. https://doi.org/10.1016/S0377-0273(99)00108-0

White JDL, Valentine GA (2016) Magmatic versus phreatomagmatic fragmentation: absence of evidence is not evidence of absence. Geosphere 12(5):1478-1488. https://doi.org/10.1130/GES01337.1

Wohletz KH (1983) Mechanisms of hydrovolcanic pyroclast formation: grain-size, scanning electron microscopy, and experimental studies. J Volcanol Geotherm Res 17(1):31-63. https://doi.org/10.1016/0377-0273(83)90061-6

Wohletz KH, McQueen RG (1984) Volcanic and stratospheric dustlike particles produced by experimental water-melt interactions. Geology 12(10):591-594. https://doi.org/10.1130/0091-7613(1984)12<591:VASDPP>2.0.CO;2

Wohletz KH, Sheridan MF (1983) Hydrovoleanic explosions, I, evolution of basaltic tuff rings and tuff cones. Am J Sei $283(5): 385$ 415. https://doi.org/10.2475/ajs.283.5.385

Wohletz KH, Zimanowski B, Büttner R (2013) Magma-water interactions. Modeling volcanic processes. Cambridge University Press, New York, pp 230-257

Zanon V, Pacheco JM, Pimentel A (2009) Growth and evolution of an emergent tuff cone: considerations from structural geology, geomorphology and facies analysis of São Roque Volcano, São Miguel (Azores). J Volcanol Geotherm Res 180(2-4):277-291. https://doi.org/10.1016/j.jvolgeores.2008.09.018

Zimanowski B (2004) (The maar engine; a review) Occasional papers of the Geological Institute of Hungary 203:106107

AQ22

Zimanowski B, Fröhlich G, Lorenz V (1991) Quantitative experiments on phreatomagmatic explosions. J Volcanol Geotherm Res 48(3):341-358. https://doi.org/10.1016/0377-0273(91)90050-A 